\title{
Inuit Approaches to Naming and Distinguishing Caribou: Considering Language, Place, and Homeland toward Improved Co-management
}

\author{
Gita Ljubicic, ${ }^{1,2}$ Simon Okpakok, ${ }^{3}$ Sean Robertson ${ }^{4}$ and Rebecca Mearns ${ }^{1}$
}

(Received 15 December 2017; accepted in revised form 15 May 2018)

\begin{abstract}
Qikiqtaq (King William Island), in the Kitikmeot region of Nunavut, has been largely overlooked in caribou research to date. Qikiqtaq is shown as blank, or as having uncertain status, in the majority of caribou herd range maps. However, our work with Inuit Elders and hunters in Uqsuqtuuq (Gjoa Haven) on the southeastern coast of Qikiqtaq made it clear that caribou migrate on and off the island seasonally, and some remain on the island year-round. Caribou were identified as a local research priority in 2010, and we have worked together with Uqsuqtuurmiut (people of Uqsuqtuuq) from 2011 to 2016 to document and share Uqsuqtuurmiut knowledge of caribou movements, hunting, and habitat, as well as the importance of caribou for community diets, livelihoods, and cultural practices. In this process, it was important to understand appropriate Inuktitut terminology and local approaches to naming and distinguishing caribou in the region. Uqsuqtuurmiut do not generally distinguish caribou (tuktuit in Inuktitut) according to herds, in the way that biologists or wildlife managers do. Locally, people differentiate four main types of caribou: iluiliup tuktuit (inland caribou), kingailaup tuktuit (island caribou), qungniit (reindeer), and a mixture of iluiliup tuktuit and kingailaup tuktuit. Through these names, along with reviewing approaches to naming and distinguishing caribou in other Kitikmeot and Kivalliq communities, we emphasize how Inuit-caribou connections are articulated and enacted through language, place, and homeland. In efforts to support more inclusive and meaningful incorporation of Inuit knowledge in caribou co-management, we suggest that careful consideration of Inuit approaches to naming and distinguishing caribou could aid communication and mutual understanding. Key considerations that emerged include (1) accounting for dialectical differences, (2) understanding relative geographic references, and (3) recognizing historical and contemporary influences of traditional homelands and societies on terminology used. These considerations have potential implications for identifying and discussing caribou, as well as for new or refined approaches to monitoring caribou herds and habitats, since these approaches are often the result of how herds are defined.
\end{abstract}

Key words: caribou; Inuit knowledge; co-management; herd names; language; place; homeland; King William Island (Qikiqtaq); Gjoa Haven (Uqsuqtuuq); Kitikmeot; Kivalliq; Nunavut

RÉSUMÉ. Jusqu'à présent, les recherches sur le caribou ont largement fait abstraction de l'île Qikiqtaq (île du Roi-Guillaume), dans la région de Kitikmeot, au Nunavut. La majorité des cartes montrant l'aire de répartition du caribou laissent l'île Qikiqtaq en blanc, ou indiquent que son statut est incertain. Toutefois, notre travail auprès d'aînés et de chasseurs inuits à Uqsuqtuuq (Gjoa Haven) sur la côte sud-est de Qikiqtaq a bien prouvé que les caribous migrent sur l'île et en repartent de façon saisonnière, et que certains restent sur l'île toute l'année. Le caribou a été décrété comme sujet de recherche prioritaire à l'échelle locale en 2010, et de 2011 à 2016, nous avons travaillé en collaboration avec les Uqsuqtuurmiut (le peuple d'Uqsuqtuuq) pour documenter et partager les connaissances des Uqsuqtuurmiut sur les déplacements, la chasse et l'habitat des caribous, ainsi que l'importance du caribou pour le régime alimentaire des gens, les moyens de subsistance et les pratiques culturelles. Dans le cadre de ce processus, il était important de comprendre la terminologie appropriée en inuktitut et les approches locales prises pour nommer et distinguer les espèces de caribous de la région. Les Uqsuqtuurmiut ne distinguent généralement pas le caribou (tuktuit en inuktitut) par hardes, comme le font les biologistes ou les gestionnaires de la faune. À l'échelle locale, les gens distinguent quatre principaux types de caribous : le caribou des terres intérieures (iluiliup tuktuit), le caribou des îles (kingailaup tuktuit), le renne (qungniit) et un mélange d'iluiliup tuktuit et de kingailaup tuktuit. En ayant recours à ces noms, ainsi qu'en revoyant les approches employées pour nommer et distinguer le caribou dans les autres collectivités de Kitikmeot et de Kivalliq, nous mettons l'accent sur la façon dont les relations entre les Inuit et les caribous se manifestent et sont exprimées selon la langue, l'endroit et la patrie. Dans le but d'appuyer l'intégration plus inclusive et significative des connaissances des Inuit aux fins de la cogestion du caribou, nous croyons qu'un examen attentif des approches utilisées par les Inuit pour nommer et distinguer les caribous pourrait faciliter la communication et la compréhension mutuelle. Les principales considérations qui en découlent sont : 1) la prise en compte des différences de dialecte, 2) la compréhension des références géographiques

\footnotetext{
${ }^{1}$ Department of Geography and Environmental Studies, Carleton University, 1125 Colonel By Dr., B349 Loeb Building, Ottawa, Ontario K1S 5B6, Canada

${ }^{2}$ Corresponding author: gita_ljubicic@carleton.ca

${ }^{3}$ PO Box 81, Gjoa Haven, Nunavut X0B 1J0, Canada

${ }^{4}$ Faculty of Native Studies, University of Alberta, 2-31 Pembina Hall, Edmonton, Alberta T6G 2H8, Canada

(C) The Arctic Institute of North America
} 
relatives et 3) la reconnaissance des influences historiques et contemporaines des patries et sociétés traditionnelles sur la terminologie employée. Ces considérations ont des répercussions potentielles sur l'identification du caribou et les discussions à leur sujet, ainsi que sur l'établissement d'approches nouvelles et plus perfectionnées pour surveiller les hardes et les habitats de caribous, puisque ces approches sont souvent le résultat de la façon dont les hardes sont définies.

Mots clés : caribou; connaissances des Inuit; cogestion; nom des hardes; langue; endroit; patrie; île du Roi-Guillaume (Qikiqtaq); Gjoa Haven (Uqsuqtuuq); Kitikmeot; Kivalliq; Nunavut

Traduit pour la revue Arctic par Nicole Giguère.

\section{INTRODUCTION}

\begin{abstract}
Although Qitirmiut lifestyles have changed today compared to long ago, caribou continue to be central to culture, identity, and diet. In traditional times, people moved with the caribou and set camps along their migration routes...Qitirmiut are no longer as nomadic and do not follow the caribou as they did in the past, yet they remain concerned about the health and condition of caribou, especially given modern-day social and environmental pressures.
\end{abstract}

This excerpt from Thorpe et al.'s Thunder on the Tundra (2001b:13), is a powerful summary of the importance of caribou for Inuit in the Kitikmeot region of Nunavut. Natasha Thorpe worked with Elders and hunters from the westernmost communities in the region, but these statements also resonate strongly with our experiences in Uqsuqtuuq (Gjoa Haven, Nunavut), a bit farther east in the Kitikmeot region on the southeastern shore of Qikiqtaq (King William Island) (Fig. 1). The pressures noted in the quote above were similarly articulated in Uqsuqtuuq during early research planning meetings, where caribou were identified as a local research priority (Laidler and Grimwood, 2010). Caribou are embedded in Inuit life and culture, and have been an important part of seasonal rounds and material culture for generations (Freeman, 1976; Thorpe et al., 2001b; Bennett and Rowley, 2004; Keith, 2004; Kendrick and Manseau, 2008). Caribou remain the country food consumed in greatest prevalence and quantity by Inuit (Kenny and Chan, 2017), and continue to be highly interconnected with Inuit values, beliefs, and practices (Thorpe, 1998; Thorpe et al., 2001a; Bennett and Rowley, 2004; Kendrick and Manseau, 2008; GN, 2011; Mearns, 2017). Among early discussions in Uqsuqtuuq, the importance of caribou in Inuit identity and wellbeing was reiterated, along with concerns around invasive wildlife research practices, weakening of intergenerational transmission of cultural values and skills associated with caribou hunting, and potential future imposition of hunting quotas (Laidler and Grimwood, 2010). Underlying these concerns was a local desire to ensure that Inuit knowledge and voices are better represented and considered in research and decision-making processes. Therefore, from 2011 to 2016 we worked together with Uqsuqtuurmiut (people of Gjoa Haven) to document and share Uqsuqtuurmiut knowledge of caribou movements, hunting, and habitat, as well as the importance of caribou for community diets, livelihoods, and cultural practices. This paper addresses one of several local research priorities identified, specifically in relation to documenting and sharing Inuit knowledge of caribou on and near Qikiqtaq, with particular emphasis on Inuktitut terminology, and geographic and cultural context.

Qikiqtaq has been largely overlooked in the context of caribou research (Ljubicic et al., 2017). On the majority of herd range maps Qikiqtaq is shown as blank or is indicated as having uncertain status (COSEWIC, 2004, 2016; GN, 2011; Ljubicic et al., 2017). The available literature shows no clear consensus on which herds may be present on Qikiqtaq or are most closely relevant to Qikiqtaq and hunters traveling from Uqsuqtuuq. However, in our early research planning meetings, Elders described caribou on Qikiqtaq year-round, adding that seasonally up to four different kinds of caribou may be present in the region (Laidler and Grimwood, 2010). Therefore, understanding appropriate Inuktitut terminology and how Uqsuqtuurmiut name and distinguish caribou around Qikiqtaq became an important aspect of our collaborative research process in support of cross-cultural understanding. This emphasis on language helped to improve communications within our project, but it also raised some important considerations that are relevant beyond our project in broader caribou research and co-management contexts.

Tuktu is a general reference to "caribou" across most dialects of Inuktut (the language of the Inuit), including Inuktitut and Inuinnaqtun, which are spoken in the Kitikmeot region. This term is commonly recognized in caribou literature, but discussions of Inuit approaches to naming and distinguishing herds of tuktuit (plural of tuktu) are rare. In Nunavut, the caribou herd distinctions and range maps used to structure management plans and decisions are derived primarily from biological classification schemes and surveys (GN, 2011; GNWT, 2011; BQCMB, 2014). Although debates among biologists regarding specific herd characterizations are ongoing (Fisher et al., 2009; Zittlau et al., 2009; Gunn et al., 2011; Nagy et al., 2011; Adamczewski et al., 2015), the generally agreed-upon definition of a caribou herd is usually tied to the distinctive calving ground affiliation of female caribou (Gunn and Miller, 1986; Gunn and D'Hont, 2002; GNWT, 2011). Defined in this way, caribou herds that may be found within the Kitikmeot region, either seasonally or year-round, include the Ahiak, Bathurst, Beverly, Bluenose East, Dolphin and Union, Lorillard, Melville Peninsula, Qamanirjuaq, Peary, and 


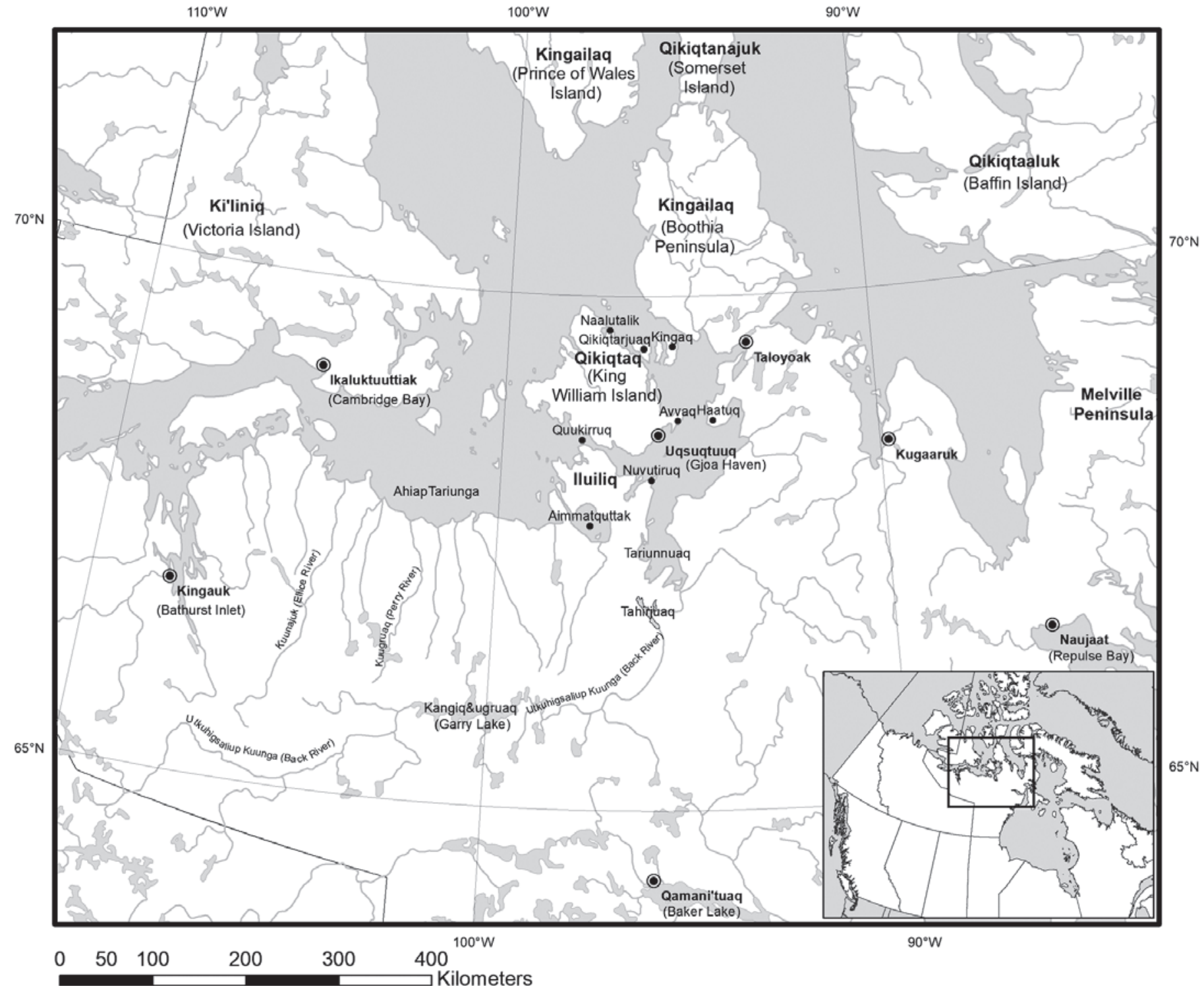

FIG. 1. Regional map showing Uqsuqtuuq (Gjoa Haven, Nunavut) on Qikiqtaq (King William Island) and other key places referred to in the text. Source of the base map for this and other map figures: GeoGratis (North American Atlas - Vector); Coordinate System - GCS_North_American_1983; Datum - North American 1983; Projection - Canada Lambert Conformal Conic. Important places and names as indicated by Uqsuqtuurmiut and mapped according to inuitplaces.org.

Wager Bay herds. Where Inuit perspectives are included in literature, government reports, and harvest studies, they are typically generalized with references to "caribou" broadly, or in relation to herds as named by biologists (e.g., Gunn et al., 2000a, 2011; NWMB, 2004; Dumond, 2007; GN, 2007, 2015; InterGroup Consultants Ltd., 2008; Kendrick and Manseau, 2008; ACCWM, 2014). Inuit approaches to naming and distinguishing caribou are not well reflected in these documents, and we feel that they deserve more nuanced discussion.

In this paper, we aim to (1) characterize Inuit approaches to naming and distinguishing caribou in Uqsuqtuuq, (2) explore the consistency of naming practices across geographic and cultural contexts in the Kitikmeot and
Kivalliq regions of Nunavut, and (3) identify some key considerations regarding language, place, and homeland that could contribute to improved communications in co-management. We highlight examples of how local dialects, relative geographic references, and traditional homelands and societies still influence how and where people interact with caribou. These aspects contribute to the diversity of Inuit approaches to naming and distinguishing caribou within or between communities and are thus critical considerations when communicating about co-management objectives. We hope that our work can contribute to broader efforts to understand Inuit-caribou connections and support more inclusive and meaningful cross-cultural relationships in caribou research and management. 


\section{Caribou Co-management Context}

Co-management of caribou (as well as other wildlife) is mandated in Nunavut through the Nunavut Agreement (GC and TFN, 1993) and operationalized through the Nunavut Wildlife Management Board, Government of Nunavut Department of Environment, regional wildlife organizations (RWOs), local hunters and trappers organizations (HTOs), and other herd-specific co-management boards (Notzke, 1995; Wheatley, 2003; White, 2006; GN, 2011). Co-management strategies emerged through efforts to address a troubling history of management decisions that were made mostly in relation to economic development, with little or no consultation on Indigenous knowledge, consideration of local cultural practices and needs, or respect of Indigenous rights through long-term land use and occupancy (Urquhart, 1996; Natcher et al., 2005; White, 2006). Co-management policy now requires equal consideration of Indigenous and scientific knowledge to inform decision making (Peter and Urquhart, 1996; Kendrick, 2000; Wheatley, 2003; Thorpe, 2004; GN, 2011; BQCMB, 2014), and a continuum of arrangements, with varying levels of sharing power and responsibility between government and local resource users, has been developed (Notzke, 1995). However, critique and discussion continue on how effectively co-management has been-or can be-implemented within cross-cultural contexts at both bureaucratic and practical levels (Notzke, 1995; Urquhart, 1996; Collings, 1997; Nadasdy, 1999, 2003; Kendrick, 2000, 2002; Kofinas, 2005; Spak, 2005; Stevenson, 2006; White, 2006; Bayha, 2012; Watson, 2013; Padilla and Kofinas, 2014). Colonial legacies, management regimes, institutional structures, ontological and epistemological assumptions, power dynamics, board representatives, decision-making timeframes, and budgetary constraints, among other factors, all interact within different contexts to limit the ways in which Inuit (or other Indigenous) knowledge can be effectively brought to and considered at the literal or figurative decisionmaking table (Notzke, 1995; Nadasdy, 1999, 2003; Kendrick, 2000; Peters, 2003; Cruikshank, 2004; Kofinas, 2005; Natcher et al., 2005; Spak, 2005; White, 2006; Watson, 2013). Indeed, co-management begins long before people come together around the table, and it involves many people not formally represented in those instances.

Research on co-management policies and practices has long recognized that co-management is not so much about managing resources as about managing relationships, and thus it is also about understanding the underlying cultural values and beliefs that influence social and ecological relationships (Osherenko, 1988; Natcher et al., 2005; Stevenson, 2006; White, 2006). This process involves "negotiation, deliberation, knowledge generation, and joint learning" across epistemologies, uncertainties, scales, and governance systems that take co-management into the realm of "complex adaptive systems" (Berkes, 2009:1698). Yet for all the discussions of co-management processes, cross-cultural dynamics, and the need to better understand each other by acknowledging and working to learn from fundamentally different epistemologies and perspectives, there is remarkably little discussion of language, geographic, and cultural context that could contribute significantly to this process.

In the context of caribou and other wildlife co-management practices in Nunavut, language comes up mostly in relation to efforts of various boards to translate meeting minutes, board policies, and procedures, and reports from English to the Indigenous language of board members (Kendrick, 2000; Stevenson, 2006; White, 2006). In this regard, there have been sincere commitments to improving communications in support of mutual understanding and more inclusive decision making. The co-management literature recognizes "the centrality of language, carrying as it does very different conceptual frameworks and ways of thinking and knowing" (White, 2006:405). However, the actions taken seem to emphasize efforts to communicate and translate principles of Western scientific caribou research - in written form - to Indigenous board representatives and their community organizations rather than a more reciprocal approach (Kendrick, 2000; Spak, 2005; Stevenson, 2006; White, 2006). Indeed, the level of Inuit and other Indigenous representatives' active participation in co-management discussions is often limited as they find themselves "participat[ing] in a process in which their interests are overwhelmed by the language and expertise of other interest groups" (Spak, 2005:238). Indigenous people often end up adopting the dominant languages, approaches, and institutions of natural resources management in order to exert influence on management decisions (Peters, 2003; Stevenson, 2006; White, 2006). This practice can undermine Indigenous values in the co-management process and threaten the ways in which Indigenous people "....understand and wish to relate to their lands, resources, and each other" (Stevenson, 2006:170). In this process, critical understandings can be lost, either through translation or through omission.

Although the co-management literature recognizes the strong connection between language and values, it contains little discussion of the specific language used in referring to the particular animals in question. From a Dene perspective, Polfus et al. (2016:17) contend that “...[I]ndigenous languages provide an obvious place to ground research processes and build collaborations. Words can be used to strengthen people's relationship with local ecosystems and create appropriate and unifying dialogue." We have much to learn from Inuktut languages in terms of how people relate to animals, and how this relationship influences different approaches to "managing" or "caring for" these animals and the habitats that support them. "Managing caribou in Nunavut is not only about ensuring that herds remain healthy and viable. It is also about preserving, protecting and enhancing the relationships between people and caribou" (GN, 2011:28). An important aspect of supporting these relationships begins with attention to communications and can evolve to foster mutual respect and understanding. 


\section{METHODS}

The work we present in this paper is part of a broader research project entitled "Connecting Inuit Elders and Youth: Caribou, community, and well-being in Gjoa Haven, Nunavut," which took place between 2011 and 2016 (Ljubicic et al., 2016). Our project evolved from an initial invitation from Uqsuqtuuq Elder Bob Konana and a partnership with the Kitikmeot Inuit Association (KIA), which helped to secure funding and facilitate early planning meetings in 2010. A three-day workshop identified the local priorities and research principles that shaped our collaborative process (Laidler and Grimwood, 2010; Ljubicic et al., in press). As part of the larger project, we undertook a systematic literature review (Ljubicic et al., 2017) and facilitated semi-directed interviews, participatory mapping, Elder-youth land camps, planning and training workshops, and results verification workshops. Only the methods specifically contributing to results presented in this paper are described below. For more on community context, collaborative process, and methods, see Ljubicic et al. (in press). On the Qaggiq Model for Inuktitut knowledge renewal that guided our relational approach throughout the project, see McGrath (2011) and Mearns (2017).

In order to understand the current status of caribou research on or near Qikiqtaq, we conducted a systematic literature review at the outset of the project. This review included searches of peer-reviewed literature using electronic databases such as Science Direct, Scholar's Portal, Scopus, and Web of Knowledge. It also included grey literature searches using government, Indigenous organization, co-management board, and independent wildlife and research committee websites for publicly available reports. Details of the literature review process and findings are provided in Ljubicic et al. (2017). The literature review also contributed specifically to this paper in that we went back through all academic and grey literature that focused on Inuit knowledge to explore the consistency of Uqsuqtuurmiut approaches to naming and distinguishing caribou with those of other Inuit communities in the Kitikmeot and Kivalliq regions. We undertook this review as an iterative process in conjunction with interpretations and discussions of naming practices that emerged from interviews and workshops. Drawing on literature from the perspective of other communities helped us to articulate more clearly the ways in which language, place, and homeland influence how Uqsuqtuurmiut think about, speak about, and engage with caribou around Qikiqtaq.

In the summers of 2012 and 2013, Sean Robertson and Rebecca Mearns (either together or alone) conducted interviews in Uqsuqtuuq, with Simon Okpakok as facilitator and interpreter. Leonie Aaluk also helped with interpreting in some interviews. The 39 interviewees (27 men and 12 women) ranged in age from early twenties to early eighties. The semi-directed interview format allowed for in-depth discussions to learn about individual experiences with and knowledge of caribou in the region, as well as the flexibility to explore topics or directions raised by different contributors (Huntington, 1998; Wenzel, 1999; Bennett, 2002). Interviews covered a range of subjects concerning the importance of caribou for community well-being, but the discussions most relevant to this paper are those about how Uqsuqtuurmiut name and distinguish different types of caribou that are found on or near Qikiqtaq and the associated Inuktitut terms. The English versions of interviews were transcribed verbatim by doctoral research assistant Stephanie Pyne, and we used both the transcripts and the audio files for iterative analyses that involved coding according to interview questions and emergent discussion themes. Mearns and Okpakok also used the Inuktitut audio files in our verification processes. We all read the transcripts and listened to the audio repeatedly, and it was through this process of multiple "listenings" that we identified important points to clarify in workshops. Through these iterations, we also began to hear patterns of language, place, and homeland emphasized in the ways that Uqsuqtuurmiut shared their stories. The quotations from interviews used throughout this paper highlight individual contributions to the collective interpretations presented. However, many of the key considerations about naming and distinguishing caribou that we present in this paper stemmed from the verification workshops and iterative discussions among the co-authors, which refined our understanding of the underlying meanings and implications of Inuit approaches to naming and distinguishing caribou in relation to cross-cultural communication.

We also incorporated participatory mapping into each interview as a way of facilitating discussion. The maps helped us to understand how people's stories related to particular places and provided spatial context for knowledge shared about caribou movements and hunting areas or observations of change (Huntington, 1998; Fox, 2002; Collignon, 2006a; Kendrick and Manseau, 2008; Aporta, 2009). The standard base map used in each interview was a compilation of NTS 1:250 000 map sheets that represented a customized region of interest determined in planning meetings (Fig. 1). The base map was used with a clear mylar plastic overlay, on which individuals were encouraged to draw relevant features that pertained to stories they were sharing. All 32 maps created through the interviews were digitized so we could compile and work with them in ArcGIS.

In the process of interview transcription and interpretation, map digitizing, and linking interview and map representations of caribou presence, movements, and hunting areas, a number of questions were raised that needed clarification. We carefully documented these questions and organized several verification workshops in 2013 and 2016. Workshops have previously been identified as an effective means of verifying results, sharing interpretations, and facilitating cross-cultural knowledge exchanges (Huntington et al., 2002; Nickels et al., 2006; Laidler et al., 2011). In the summer of 2013 , we verified 
maps with 10 individuals who had been interviewed in 2012 to clarify feature boundaries and labels and the associated timeframes and stories. In winter 2016, an intensive threeday workshop was held with five Elders who had been part of the project planning committee and had provided overall project guidance since 2011. One day was dedicated to reviewing methods, one to caribou terminology and mapping, and one to understanding connections between caribou and community well-being. Simon Okpakok and Lorraine Puqiqnak facilitated and interpreted these discussions, and we would generally continue discussing an issue or question until we reached a consensus on how best to represent Uqsuqtuurmiut knowledge on the particular issue at hand. These workshop discussions allowed us to explore more complex issues, and through this process new ways of understanding or representing Uqsuqtuurmiut knowledge emerged that had not come out of our various individual efforts. This collective interpretation and verification was therefore valuable, and indeed critical, to using appropriate terms, creating effective visualizations, and delving into more nuanced meanings of the knowledge that was shared throughout the project. During this 2016 visit, we also shared preliminary results at a community gathering and celebration in Uqsuqtuuq. We engaged in ongoing clarification efforts, facilitated by Simon Okpakok, up to the time of submitting this paper in December 2017. Wherever possible, workshop contributions are cited directly in the text using "WKSP" as an identifier for a particular group discussion.

\section{Inuktitut Terminology}

Throughout our work together, Uqsuqtuurmiut contributors emphasized the importance of the Inuktitut language, so we use Inuktitut terminology and place names wherever possible in this paper. Spellings are according to Simon Okpakok's Utkuhigsaligmiut dialect. These may vary in other dialects present in Uqsuqtuuq, although the terms are mutually understood. Inuktitut or Inuinnaqtun spellings in references cited maintain the spelling from the original text and thus may also be different. In general, we capitalize Inuktitut place names to highlight these as toponyms, but do not capitalize caribou names or other terms (unless they are capitalized in texts we cite).

We use "Uqsuqtuurmiut knowledge" as a collective reference to the knowledge shared in this paper for two reasons. First, it became clear during interview discussions that many contributors did not identify with Inuit Qaujimajatuqangit (IQ) terminology (Ljubicic et al., in press), although it has become more common in literature since being formalized in GN policy and language (Wenzel, 2004; Tester and Irniq, 2008; GN, 2013). Second, we emphasize that knowledge shared in this paper is based on experiences from Uqsuqtuuq and from people's travels in surrounding areas. Therefore, we use Uqsuqtuurmiut knowledge to reflect the cultural and regional context in which this knowledge was acquired and to acknowledge that community contributions to this project cannot be extended or generalized to represent knowledge from other Kitikmeot or Nunavut communities. When writing more generally, we use "Inuit knowledge" or other terms used in the literature we refer to.

In relation to place names, we incorporate commonly used Inuktitut names in the text and on maps, although some English names are included as well to help readers orient themselves. English place names may also be used if referring to literature in which these names are used. In the context of Uqsuqtuuq, Qikiqtaq is a specific reference to the island known in English as King William Island (Fig. 1). It is important to note that Qikiqtaq is also a general term meaning "island" in Inuktitut, and so there may be many islands with this name across Nunavut; however, all references to Qikiqtaq in this paper relate to King William Island unless otherwise noted.

The quotations from Uqsuqtuurmiut interviews that are included in this paper maintain the English used by the interpreter, as we relied on the interpreter to facilitate crosscultural communication. We have not adjusted caribou names or place names in these quotations to be in Inuktitut, out of respect for the choices made by the interpreter during interviews. Where the terms "Peary caribou" or "barrenground caribou" appear in these quotations, it is because the interpreter (or the interviewee, when speaking English) was translating the Inuktitut names to English and biological terms. However, it was through this process of translation that Okpakok and Mearns began to notice patterns. Through iterative discussions amongst ourselves, we were able to discern different names for caribou, related terms, and important places. Therefore, it was only after multiple times of reading transcriptions, listening to interview audio, clarifying key terms through workshop discussions, and discussing interpretations amongst ourselves that we began to see the connections between language, place, and homeland that we emphasize in this paper. These reflections on translation enabled us to better understand each other and to consider how translation influences communication in broader research and management contexts (Ljubicic et al., in press).

\section{UQSUQTUURMIUT APPROACHES TO NAMING AND DISTINGUISHING CARIBOU}

To learn more about the four different kinds of caribou that were mentioned in relation to Qikiqtaq during early planning meetings in Uqsuqtuuq (Laidler and Grimwood, 2010), we asked specific questions in interviews about how Uqsuqtuurmiut name and distinguish different caribou herds. We received a wide array of responses. Initially, most people would explain that, in general, Inuit do not distinguish caribou herds or do not know which herds are coming onto Qikiqtaq (Akkikungnaq, 2013; Eleehetook, 2013; Putuguq, 2013; Qitsualik, 2013; WKSP, 2013a, b, 2016a). David Siksik, a member of the land camp planning 
committee, elaborated on these comments during our verification workshop in February 2016 (WKSP, 2016a):

Caribou are referred to as caribou-by our ancestors, they were referred to as caribou. We knew of many regions within our knowledge, however no one can refer to any type of caribou as being from a certain place. During the spring migration we know that there are caribou moving from the south to the north then from the west to the east. Because the land is so vast, we do not state exactly where the caribou are coming fromthere is no particular area as to where the caribou started from but rather a direction from which they had originated.

Caribou are most commonly referred to by their Inuktitut name tuktuit, and distinguishing different herds is not considered important or necessary according to Inuit values and hunting culture. Siksik continued his explanation in WKSP (2016a):

King William Island does not have its own caribou; they are caribou that are coming from the mainland during spring. There were also, at one time, Peary caribou crossing over here. But the main ones crossing today are coming from the mainland to the island. The caribou do not stop moving; they are coming from the Kugluktuk area [to the west] and from Baker Lake [to the south]. They come from all directions. The caribou that are coming to the island are a mix of different caribou herds.

Nevertheless, throughout interviews and workshop discussions, the importance of seasonal movements was emphasized, along with additional details that emerged with regard to size, colour, sex, taste, timing, and likely origin of caribou. The most consistent distinctions were made between iluiliup tuktuit, which come onto Qikiqtaq from the mainland to the south, and kingailaup tuktuit, which come onto Qikiqtaq from the islands in the Canadian Arctic Archipelago to the north (Fig. 2, Table 1). Other common terms related to sex and life stage are summarized in Table 2.

\section{Iluiliup Tuktuit (Inland Caribou)}

Iluiliup tuktuit refers to caribou coming from the mainland (Sallerina, 2012; Aqslaluk, 2013; Putuguq, 2013; WKSP, 2013b, 2016a) and is commonly translated into English as barren-ground caribou (Rangifer tarandus groenlandicus) (Table 1). Iluiliq is a local dialectical reference to 'inland' or 'mainland' (mainly used to refer to the Adelaide Peninsula), so the Inuktitut literally means 'caribou belonging to the mainland.' "Inuit know there are different types of caribou...iluiliup tuktuit are from the mainland...they are much bigger" (Siksik in WKSP, 2016a). These caribou are also commonly described as "big" (angijuq) caribou (Putuguq, 2013; WKSP, 2013c, d, 2016a) or "real" or "regular" caribou (WKSP, 2013d, 2016a). Iluiliup tuktuit move back and forth from the mainland to Qikiqtaq, migrating north in the spring and south in the fall, with some caribou remaining on the island year-round (Arqviq, 2012; Sallerina, 2012; Aqslaluk, 2013; Eleehetook, 2013; Putuguq, 2013; see Ljubicic et al. [in press] for more context on seasonal movements) (Fig. 2).

\section{Kingailaup Tuktuit (Island Caribou)}

In contrast, kingailaup tuktuit refers to caribou coming from the islands north of Qikiqtaq (Aglukkaq, 2012; Sallerina, 2012; Akkikungnaq, 2013; Aqslaluk, 2013; Putuguq, 2013; WKSP, 2013b, 2016a). Kingailaup tuktuit is the term used generally to describe caribou from the islands in the Canadian Arctic Archipelago and thus is commonly translated into English as Peary caribou (Rangifer tarandus pearyi) (Table 1). However, the literal meaning is 'caribou belonging to kingailaq ['a place with no mountains']' (Sallerina, 2012; Aqslaluk, 2013; WKSP, 2013a, b, 2016a). When we asked for clarification on this place, kingailaup tuktuit was always translated as a specific reference to the island directly north of Qikiqtaq, known in English as Prince of Wales Island, although Kingailaq is also the Inuktitut name for Boothia Peninsula (Fig. 1). Kingailaup tuktuit are known to move onto Qikiqtaq from the islands farther north and commonly travel through Kingailaq (Prince of Wales Island) (Sallerina, 2012; WKSP, 2013b, d) or Qikiqtanajuk (Somerset Island) via Kingailaq (Boothia Peninsula) (Arqviq, 2012) to reach Qikiqtaq (Fig. 2). They are also said to move across to Qikiqtaq from Kingailaq (Boothia Peninsula) to the east (Aglukkaq, 2012; Arqviq, 2012; Sallerina, 2012; Akkikungnaq, 2013; Aqslaluk, 2013; Putuguq, 2013; WKSP, 2013b, c) or from Ki'liniq (Victoria Island) to the west (Arqviq, 2012; Sallerina, 2012; WKSP, 2013b, c, d) (Fig. 2).

When I first moved to Gjoa Haven from Taloyoak, there was not very much caribou on the Island. You'd get Peary caribou from Prince of Wales [Island]... the Inuktitut name is Kingailaq, 'a place with no mountains'...We call [those caribou] kingailaup tuktuit...the small little Peary caribous come from Prince of Wales Island...I'm assuming they come by Boothia [Peninsula] because it comes all the way up...or maybe by Victoria [Island], because they also had them on Victoria Island.... (Sallerina, 2012)

Kingailaup tuktuit are distinguished from iluiliup tuktuit primarily by their size and hair colour. Kingailaup tuktuit are frequently described as the caribou that are "small" (mikijuq) and "white" (kakuqtuq) (Sallerina, 2012; Akkikungnaq, 2013; Aqslaluk, 2013; Putuguq, 2013; WKSP, 2013b, c, d, 2016a). Although this reference to the whiter hair of kingailaup tuktuit is common, they are not to be confused with a rare albino (pukiq) caribou (WKSP, 


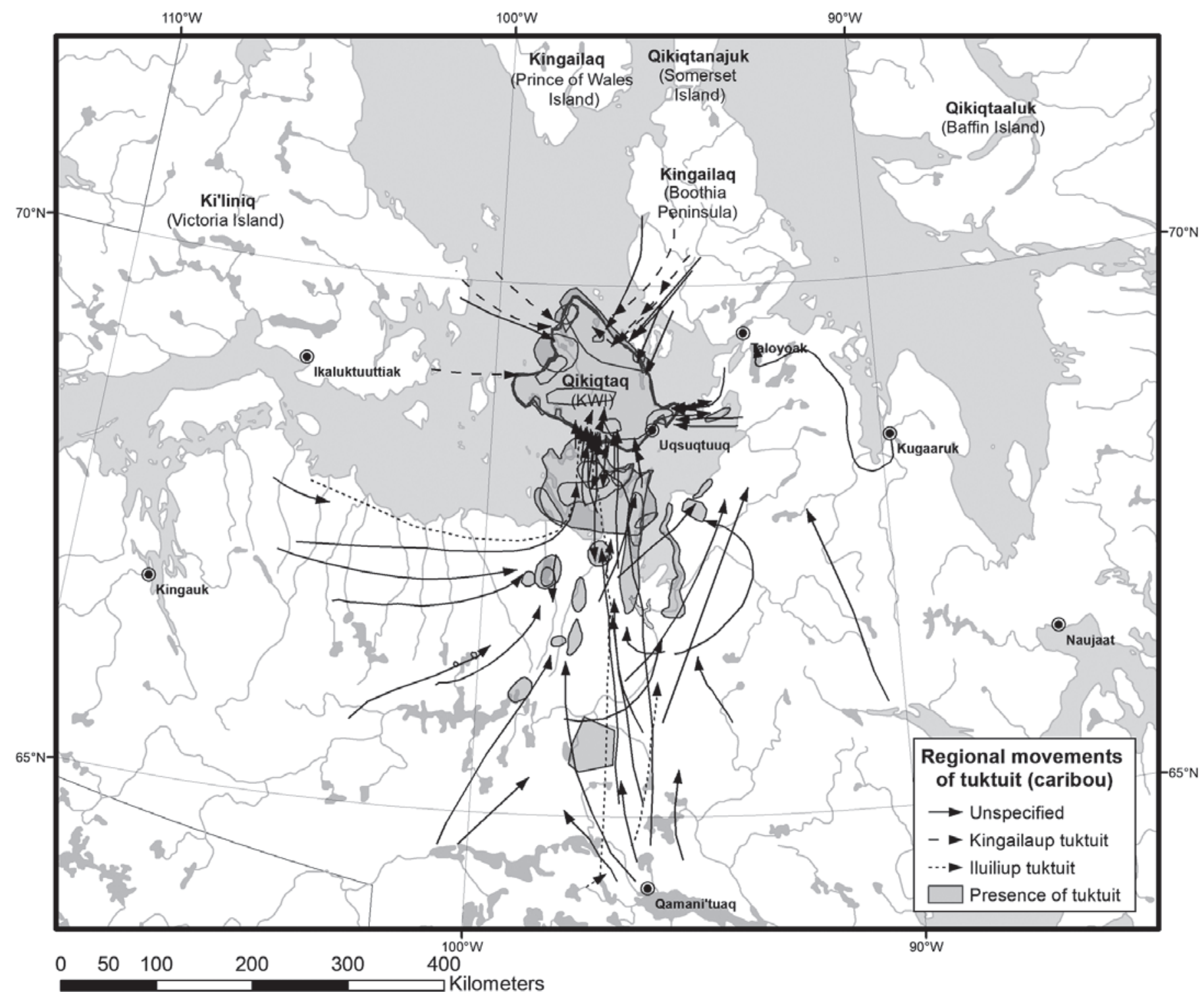

FIG. 2. Regional movements of tuktuit (caribou) around Qikiqtaq. The directional arrows are shown as they were drawn (or not) in interviews. Most of these depict tuktuit moving northwards to Qikiqtaq in spring, but Uqsuqtuurmiut also described seasonal movements on and off the island, with the exception of some tuktuit that remain on the island year-round. Each of the lines can be considered as having bi-directional arrows since, for the most part, tuktuit also move off Qikiqtaq in the fall. Sources: Aaluk (2012), Aglukkaq (2012), Akoak (2012), Arqviq (2012), Atkichok (2012), Eleehetook (2012), Hiqiniq (2012), Keanik (2012), Konana (2012), Puqiqnak (2012), Sallerina (2012), Siksik (2012), Tavalok (2012), Akkikungnaq (2013), Aqslaluk (2013), Atkichok (2013), Eleehetook (2013), Kamamalik (2013), Qitsualik (2013), WKSP (2013d).

2016a). Mary Aqilriaq talked about how rare it was to come across a pukiq in WKSP (2016a); when she has seen them, they tended to be large male caribou that are all white. The name pukiq refers to the white belly hair of the caribou, but it is also specifically used to describe an albino caribou that is white all over. Kingailaup tuktuit are also described as having thicker and longer hair than iluiliup tuktuit, as well as shorter and wider legs (Akkikungnaq, 2013; WKSP, 2013d, 2016a). Akkikungnaq (2013) also discussed identifying kingailaup tuktuit by the taste of their meat: these island caribou taste saltier because they eat a lot of seaweed. In addition to these most common "inland" and "island" caribou, reindeer and mixed caribou were also identified as being present in the region.

\section{Qungniit (Reindeer)}

During an interview, Tommy Tavalok described "Alaskan caribou" on Qikiqtaq and likened these to reindeer (Tavalok, 2012). He explained that he had only seen - and caught - such a caribou once in his life. This reindeer was not like kingailaup tuktuit, it was like caribou that would be seen in Alaska (WKSP, 2013c). Reindeer near Qikiqtaq had also been mentioned in early planning workshops (Laidler and Grimwood, 2010). However, no one other than Tavalok mentioned reindeer in interview discussions, so we asked about them in the 2016 verification workshop. Both David Siksik and Donald Kogvik grew up far west of Uqsuqtuuq around Kuugruaq (Perry River). 
TABLE 1. Inuit ways of naming and distinguishing tuktuit (caribou) in the Kitikmeot Region of Nunavut.

\begin{tabular}{|c|c|c|c|c|}
\hline Inuktut name & Translated meaning & Source $^{1}$ & Closest biological reference & Notes \\
\hline Tuktuit & General reference to caribou & All & Caribou & $\begin{array}{l}\text { There may be slight spelling variations by dialect, but tuktu } \\
\text { (tuktuit in plural) is a general reference to caribou across the } \\
\text { Inuktut language. }\end{array}$ \\
\hline Iluiliup tuktuit & Inland (mainland) caribou & Uqsuqtuurmiut & Barren-ground caribou & $\begin{array}{l}\text { Most Uqsuqtuurmiut do not distinguish between types of } \\
\text { iluiliup tuktuit. }\end{array}$ \\
\hline Kingailaup tuktuit & Island caribou & Uqsuqtuurmiut & Peary caribou & $\begin{array}{l}\text { The Inuktitut is a specific reference to Kingailaq (Prince } \\
\text { of Wales Island) and is translated locally as Peary caribou, } \\
\text { although it may potentially be a reference to Arctic-island } \\
\text { caribou given geographic emphasis. }\end{array}$ \\
\hline Qungniit & Reindeer & Uqsuqtuurmiut & Reindeer & $\begin{array}{l}\text { Reindeer are known to escape reindeer herding operations at } \\
\text { times, from around Tuktoyaktuk, Northwest Territories, and } \\
\text { are also referred to as Alaskan caribou. }\end{array}$ \\
\hline N/A & Mixed caribou (cross-breed) & Uqsuqtuurmiut & $\mathrm{N} / \mathrm{A}$ & $\begin{array}{l}\text { Caribou that are a mixture of iluiliup tuktuit and kingailaup } \\
\text { tuktuit have been observed, but are uncommon and so there is } \\
\text { no Inuktitut term. }\end{array}$ \\
\hline Ahiarmiut & Mainland caribou & Qitirmiut & Barren-ground caribou & $\begin{array}{l}\text { Most Qitirmiut do not distinguish between types of } \\
\text { Ahiarmiut. }\end{array}$ \\
\hline Kiilliniq & Island caribou & Qitirmiut & Dolphin and Union caribou & $\begin{array}{l}\text { The Inuinnaqtun name specifically refers to Kiilliniq } \\
\text { (Victoria Island), and Inuit consider this to be a mix of } \\
\text { Bathurst and Peary caribou. }\end{array}$ \\
\hline N/A & Heinz 57 (cross-breed) & Qitirmiut & Ahiak caribou herd & $\begin{array}{l}\text { Caribou have been observed that are considered to be a mix } \\
\text { of Kiilliniq and Bathurst herds and are associated with the } \\
\text { Ahiak herd according to local interpretations, but these are } \\
\text { uncommon and so there is no Inuinnaqtun term. }\end{array}$ \\
\hline
\end{tabular}

${ }^{1}$ Uqsuqtuurmiut refers to the specific contributors from Uqsuqtuuq who were interviewed as part of our project. Qitirmiut refers to the specific contributors from Umingmaktuuk, Kingauk, Kugluktuk, Ikaluktuuttiak, and Hanigakhik who were interviewed as part of the Tuktu and Nogak Project (Thorpe et al., 2001a, b).

They have distinct memories of what they referred to in Inuktitut as qungniit (singular is qungniq) and described them as reindeer from Alaska or the Tuktoyaktuk area of the Northwest Territories (NWT) (WKSP, 2016a). Kogvik and Siksik explained that qungniit are identified by their migration pattern as well as by their physical characteristics (WKSP, 2016a).

The way to identify qungniit [is that] the migration comes from the west side through Tuktoyaktuk and [they] start being seen around month of July heading southward...they are different from caribou in that their hair is longer and stiffer and they're more spotted. Their front legs are shorter than the back legs, so the body appears to be longer because of the short legs...When you see them migrating, it looks like a flowing river [as they are mixed in with other large herds migrating from the west]." (Kogvik in WKSP, 2016a)

As Kogvik and Siksik explained, these qungniit were known to have escaped from reindeer herding operations in the Northwest Territories (WKSP, 2016a). Reindeer herding was introduced by the federal government in the Mackenzie Delta region around the mid-1930s as a response to cessation of caribou herd migrations in the region (Usher, 1976; Stern and Gaden, 2015; Wohlberg, 2015). These reindeer, originating from Russia and Norway, were initially brought from Napaktolik, Alaska, to Reindeer Station, just north of present-day Inuvik (Usher, 1976; Wohlberg, 2015). Saami people (Indigenous reindeer herders of Scandinavia and northern Russia) were brought to train local Inuvialuit in herding practices as part of the Canadian Reindeer Project (Wohlberg, 2015). Since the 1970s, residents of Reindeer Station have re-located to Inuvik and Tuktoyaktuk, and the semi-domesticated reindeer herds are now co-owned by the Binder Family and the Inuvialuit Regional Corporation through the Canadian Reindeer Company (Stern and Gaden, 2015; Wohlberg, 2015). Although this herding practice was fairly localized to the Mackenzie Delta, Kogvik was well aware of reindeer herding around Tuktoyaktuk. He described how qungniit sometimes strayed away and became mixed in with the large herds of caribou migrating eastward, which explains why they would be seen around Kuugruaq or as far east as Qikiqtaq (WKSP, 2016a). He had accidentally caught qungniit in the past, only realizing this as he went to retrieve the animal and saw the clipped ear and distinctive brand that identified the owner of the reindeer (WKSP, 2016a). 
TABLE 2. Additional Uqsuqtuurmiut names and ways of distinguishing tuktuit.

\begin{tabular}{|c|c|c|}
\hline Inuktitut term $^{1}$ & Translated meaning & Notes \\
\hline ataaqtuq & $\begin{array}{l}\text { Northward movements of tuktuit towards the coast in the spring } \\
\text { (usually in reference to iluiliup tuktuit). }\end{array}$ & $\begin{array}{l}\text { Some people also refer to this as atirtut, which describes the } \\
\text { movement of people going to the coast for seal hunting in the spring, } \\
\text { but can sometimes be used in reference to movements of tuktuit. }\end{array}$ \\
\hline amitrat & $\begin{array}{l}\text { When caribou are traveling together in large numbers and } \\
\text { walking along one trail. }\end{array}$ & \\
\hline kangimukpalliajut & $\begin{array}{l}\text { Southward movements of tuktuit from the coastal area towards } \\
\text { inland areas in the fall (usually in reference to iluiliup tuktuit). }\end{array}$ & $\begin{array}{l}\text { In another local dialect, this is also known as taggaaruq, which } \\
\text { means "rushing up to the mainland." }\end{array}$ \\
\hline kulavak & A full grown female $t u k t u$, whether with or without a yearling. & $\begin{array}{l}\text { Arnaluq is also used as a very general reference to any female } \\
\text { animal, including a tuktu. }\end{array}$ \\
\hline nuralik & A female $t u k t u$ with a calf. & \\
\hline nuraq & A calf, from birth to about a year old. & \\
\hline nukatugaq & A young $t u k t u$, about two years old. & \\
\hline uhuligaarruk & A young male tuktu. & \\
\hline nagruligruaq & $\begin{array}{l}\text { A male tuktu that is almost fully grown, with full antlers, but } \\
\text { whose antlers are thinner than those of an adult male. }\end{array}$ & $\begin{array}{l}\text { This tuktu is not yet a pangniq; the antlers distinguish between the } \\
\text { two. }\end{array}$ \\
\hline pangniq & A full-grown, adult male $t u k t u$. & \\
\hline pangnivik & An older male tuktu. & \\
\hline pukiq & An albino caribou. & A pukiq is seen very rarely. \\
\hline
\end{tabular}

${ }^{1}$ Inuktitut terms listed are just some of the terms most commonly referred to during discussions in Uqsuqtuuq. There are many more specific terms that refer to body, antler, and hair conditions of caribou, as well as detailed terminology for all the different bones and body parts as identified for different uses when butchering a caribou. A full listing is beyond the scope of this paper, but such terms would be important for more detailed discussions on caribou health and local uses.

\section{Mixture of Iluiliup Tuktuit and Kingailaup Tuktuit}

During interviews and workshops, participants occasionally mentioned caribou that seemed to be a "mixture" or "cross-breed" of iluiliup tuktuit and kingailaup tuktuit (Arqviq, 2012; Carter, 2012; Sallerina, 2012; WKSP, 2013b). In WKSP (2013b), the group described these mixed caribou as "island" caribou but distinguished them from kingailaup tuktuit. Joanni Sallerina (2012) describes when he noticed this kind of mixed caribou:

My uncle did a lot of trapping up north, and every time they were trapping up north he came back with a Peary caribou. There was no barren-ground then [in the 1980s]. But around the 1990s, we get mixtures of barren-ground and Peary caribou, and sometimes you'd see a mix of both. It's half Peary and half barrenground...Yeah, they're taller than Peary caribou, but they have the Peary caribou facial structure, which is short and small head.

This mixed caribou was also said to have short front legs, long back legs, and a long nose, as well as softer, more tender fat, in comparison to the mainland caribou
(WKSP, 2013b). It seems that the mixed caribou is a more recent phenomenon; it has been seen on Qikiqtaq only since the return of caribou to the island between the $1980 \mathrm{~s}$ and 1990s (Sallerina, 2012; Ljubicic et al., in press). We sought clarification on these few, inconsistent descriptions of mixed caribou in WKSP (2016a); however, the Elders commented that according to their understanding, they were not familiar with a "mixed breed" caribou.

The descriptions above highlight the ways of naming four types of caribou around Qikiqtaq as iluiliup tuktuit, kingailaup tuktuit, qungniit, and a mixture of iluiliup tuktuit and kingailaup tuktuit. The first two names are most common, as these are the types of tuktuit seen most regularly on and near Qikiqtaq. The indicators used to distinguish these tuktuit comprise the size (body and head), hair (colour and thickness), leg length, and taste of the meat, as well as the timing and direction of their movements. Beyond such regional distinctions, tuktuit were also frequently identified in relation to places near where they are found, or places they are known to migrate to and from. These references mainly emphasized the names of communities, camps, and other places. Through discussion of the likely origin of tuktuit, hunters also shared their observations of directional movements. 
Place Names Used to Identify Tuktuit Locations and Movements

Perhaps the most frequent of these geographic references was the community of Qamani'tuaq (Baker Lake) (Aaluk, 2012; Aglukkaq, 2012; Konana, 2012; Okpakok, 2012; Tavalok, 2012; Akkikungnaq, 2013; WKSP, 2013a, d). Approximately $500 \mathrm{~km}$ south of Uqsuqtuuq, Qamani'tuaq is located inland at the mouth of the Thelon River where it opens into Baker Lake, in the Kivalliq Region of Nunavut (Fig. 1). The migrations of iluiliup tuktuit to and from Qikiqtaq throughout the year were most often described in terms of when the caribou started moving north from Qamani'tuaq in the spring or moving back south towards that area in the fall (Fig. 2). These north-south caribou migrations are so prominent and important that the directional herd movements have names of their own: ataaqtuq 'going from inland towards the shore [coast]' refers to the northward migration of caribou to coastal areas in the spring, and kangimukpalliajut 'moving from the coastal area inland' (Akkikungnaq, 2013; WKSP, 2016a) describes their southward movements in the fall (see also Ljubicic et al., in press) (Table 2). Sometimes caribou from Qamani'tuaq were also said to be coming from the east on the mainland, or even from the northeast across from Kingailaq (Boothia Peninsula) (WKSP, 2013a). Those who were familiar with biological herd names and ranges described these caribou as being part of the Beverly herd (Aglukkaq, 2012; Okpakok, 2012), but mostly people referred to the community of Qamani'tuaq. However, this was only one among many communities referred to during interviews. The communities of Taloyoak (Spence Bay), Kugaaruk (Pelly Bay), and Ikaluktuuttiak (Cambridge Bay) were also mentioned often as people described their experiences from times of having lived in these communities. They would also hear from family or other hunters in these communities about the timing and direction of caribou movements, and then they would know when to expect the caribou around Qikiqtaq.

In addition to community names, important camp and place names were often used to contextualize the areas where caribou are known to be (or that they move through) or to identify preferred hunting areas. For example, Akkikungnaq (2013) explained that he would first identify the land (i.e., by place name) and then refer to the caribou found there, in order to be more specific about the caribou he is talking about. The places most frequently referred to in relation to caribou presence or movements around Qikiqtaq included Kingailaq (Boothia Peninsula), Kingaq (Matty Island), Qikiqtarjuaq (Qikiqtarjuaq Island), Nuvutiruq (Richardson Point), Iluiliq (Adelaide Peninsula), Utkuhigsaliup Kuunga (Back River), Kangiq\&ugruaq (Garry Lake), Ki'liniq (Victoria Island), Kingailaq (Prince of Wales Island), Haatuq (no known English translation), Naalutalik (Port Parry), Kuugruaq (Perry River), and Avvaq (Mount Matheson) (Figs. 1, 2). Elders also emphasized the camp names of places where they grew up (i.e., prior to settlement in Uqsuqtuuq) as being important for caribou hunting according to seasonal migrations. Hunters often reiterated that they do not use specific names for caribou herds (as biologists do); rather, their approach to naming reflects distinguishing characteristics of the caribou. Place names and other geographic references are especially important in identifying and communicating where caribou are coming from or moving to. Referring to caribou in relation to specific places thus helps to inform travel and hunting plans, provide information about direction and timing of caribou movements, and contextualize hunting stories. It also implies understandings of caribou habitat and seasonal rounds that are based on people's personal experience with caribou through hunting culture. This knowledge is shared collectively and communicated between family generations within the community, as well as between communities. This sharing may be done in person, by phone, or through radio (i.e., public radio broadcast or short-wave radio while out hunting) and even increasingly through social media.

\section{OTHER INUIT APPROACHES TO NAMING AND DISTINGUISHING CARIBOU}

In order to explore how caribou naming practices in Uqsuqtuuq may be similar to or different from practices in other Nunavut communities, we reviewed available literature for any other discussions of Inuit approaches to naming and distinguishing caribou. We focused on research in the Kitikmeot and Kivalliq regions, as terminology from communities in these regions would be most likely to overlap with that used in Uqsuqtuuq in relation to current or historical caribou hunting.

\section{Kitikmeot Region}

In the Kitikmeot region, the most thorough collaborative research highlighting Inuit knowledge of caribou was conducted by Thorpe et al. (2001a, b), and these studies also provide the most comprehensive discussions of caribou distinctions in Inuinnaqtun. The Tuktu and Nogak Project (1996-2000) was part of the larger West Kitikmeot Slave Study (Thorpe, 1997). The focus was on caribou that scientists know as the Bathurst herd, as these caribou are of central importance to collaborators from Hanigakhik (Brown Sound), Ikaluktuuttiak (Cambridge Bay), Kingauk (Bathurst Inlet), Kugluktuk (Coppermine), and Umingmaktuuk (Bay Chimo). Qitirmiut Elders (the collective reference to Elders involved from these communities in the Kitikmeot region) describe hunting several different "kinds" of caribou, including Ahiarmiut and Kiilliniq caribou.

One herd, what scientists call the "Bathurst" and "Queen Maud" caribou, is collectively known as Ahiarmiut, or the "mainland" or "barrenland" caribou 
herd, since most elders and hunters do not distinguish between different herds of Ahiarmiut. Some Ahiarmiut caribou spend the winter south of the tree line in Indian lands. Come spring, the caribou return to Inuit land, moving northward through Contwoyto Lake, and to the Bathurst Inlet area. Another herd, the Kiilliniq ("Victoria Island") caribou, spends the winters on the mainland and migrates to Victoria Island for the summers. Ahiarmiut caribou are larger and darker than the smaller and whiter Kiilliniq caribou...Some people have heard about and occasionally seen very small caribou that look like yearlings in size although they are adults. Caribou from this herd are known to live in the northern parts and northwards of Kiilliniq (Victoria Island). These are known as Peary caribou and are not discussed in this chronicle. (Thorpe et al., 2001a:79)

Ahiarmiut refers to caribou on the mainland and literally means 'from the berries' (Thorpe et al., 2001b:193), while Kiilliniq is the Inuinnaqtun name for Victoria Island (Thorpe et al., 2001b:194). The origins of the Kiilliniq caribou are said to be a mixing of Bathurst and Peary caribou (Thorpe et al., 2001b), and thus the term seems to refer to what scientists distinguish as the Dolphin and Union (DU) herd of Victoria Island (Gunn et al., 1997; Gunn and Fournier, 2000; Nagy et al., 2009; Dumond et al., 2013). Observations of increasing overlap between the ranges and migration routes of Ahiarmiut and Kiilliniq caribou prompted some mention that another herd had emerged as a mixture of the two. Locally this mixed caribou was referred to as the "Heinz 57" herd and was associated with the Queen Maud (Ahiak) herd as distinguished by scientists (Thorpe et al., 2001a:80). However, this statement was also qualified with a reminder that most Qitirmiut do not distinguish between types of Ahiarmiut caribou, so an Inuinnaqtun name for this herd had not gained popularity (Thorpe et al., 2001a). As noted above, Qitirmiut most commonly differentiate caribou herds by their size, as well as the colour and quality of their hair (Thorpe et al., 2001a). In a table summarizing Inuinnaqtun names for caribou, additional distinctions are based on caribou age, sex, hair and antler condition, reproductive stage, and season (Thorpe et al., 2001a:34). Thorpe et al. (2001a, b) also contain many references to bays, inlets, lakes, rivers, and places where people were originally from, which serve to identify more specifically where caribou would gather, migrate, and calve, as well as preferred hunting areas.

The only other Kitikmeot Inuit-focused caribou discussion we were able to locate was the report of the Western Kitikmeot Caribou Workshop hosted in Kugluktuk in the winter of 2007 (Dumond, 2007). This workshop brought together Kugluktuk Elders and hunters, and Government of Nunavut biologists and conservation officers to share their knowledge of caribou herds and work together to address concerns related to declining mainland herds. Although biologists and community members reference "mainland" and "island" caribou throughout their discussions, the section on caribou herd names and ranges in the region describes the Bluenose East and DU herds as being the most important for Kugluktuk (Dumond, 2007). All subsequent discussions highlight these two herds, as well as the Bathurst herd; however, there is no mention in the final report of how Kugluktuk Elders and hunters name or distinguish caribou herds in the region. DU caribou are indicated as being synonymous with "island caribou," and both names are used interchangeably throughout (Dumond, 2007).

\section{Kivalliq Region}

As Uqsuqtuurmiut spoke of iluiliup tuktuit traveling as far south as Qamani'tuaq (Baker Lake), it is also useful to look to the Kivalliq region to learn how Inuit there name and distinguish caribou. The most extensive work done in this regard was part of Anne Kendrick's doctoral thesis research (2001-04) in collaboration with Inuit Elders and hunters from Qamani'tuaq and Arviat to learn about the Beverly and Qamanirjuaq barren-ground herds (Kendrick, 2003; Kendrick and Manseau, 2008). The Beverly and Qamanirjuaq Caribou Management Board (BQCMB) defines these herds and indicates that their names derive from the nearby lakes around which each herd's calving grounds are concentrated (BQCMB, 1996; InterGroup Consultants Ltd., 2008). For the Beverly herd, this definition was updated in BQCMB (2014) to include the Queen Maud Gulf area. However, in the literature we find no clear description of either the literal meaning of these names or whether or how these names reflect Kivalliq Inuit practices of naming or distinguishing caribou. Interestingly, the Nunavut Living Dictionary (CLEY, 2017) defines Beverly caribou in English in relation to Baker Lake, but the Inuktitut definition is tivjaliup miksaanimiutait tuktut, which Mearns and Okpakok translate as 'caribou coming from around the area of tivjali.' Tivjali means 'a place with driftwood.' Qamanirjuaq caribou are defined in English as "Caribou herds found on the west side of Hudson Bay and north of Manitoba. Sometimes the herds travel into northern Manitoba. The calving grounds are found west of Rankin Inlet." However, in Inuktitut this herd is defined as qamanirjuap miksaanimiutait tuktut (CLEY, 2017), which Mearns and Okpakok translate as "caribou coming from around the area of qamanirjuaq" ('a large body of water (lake) in between two rivers that are flowing into and out of the lake, at either end'; CLEY, 2017). So the English definitions from the Nunavut Living Dictionary refer to community names and broader regions, while the Inuktitut definitions are more descriptive of the particular characteristics of the places named.

Qamani'tuaq is the community closest to the calving grounds of the Beverly and Qamanirjuaq herds, while Arviat is on the spring and fall migration routes of the Qamanirjuaq herd. Kendrick and Manseau (2008) used interview excerpts and maps to depict collective community experience of lifetime and seasonal harvesting, but they make no distinction between the two herds. Discussions 
refer to caribou generally, and it seems that hunters were not explicitly asked to represent their experiences in relation to a particular herd or to explain how or whether they distinguish caribou herds. Some mentions are made of the overlapping ranges of the Beverly, Qamanirjuaq, Wager Bay, Lorillard, and Ahiak herds, but it is unclear whether these statements emerged from interviews or were based on known distributions from surveys or satellite collar studies. Kendrick and Manseau (2008:414) emphasize that "Hunters and elders often make distinctions between caribou populations in relation to the direction animals have traveled from in relation to other populations; that is, Baker Lake elders speak of the Arviamiut caribou or "caribou moving from Arviat" (Qamanirjuaq caribou) that move into the Baker Lake area at certain times of year." These distinctions are also reflected in interview quotes provided throughout the paper, which highlight references to water bodies, communities, or directional movements. This unique study, which linked hunters' observations with data from satellite collars tracking caribou movements, produced many important findings and management recommendations; however, the Inuit approaches to naming or distinguishing caribou in the Kivalliq region are not fully explored in terms of their potential implications for collaborative caribou management efforts.

\section{CARIBOU NAMING GROUNDED IN LANGUAGE, PLACE, AND HOMELAND}

What we initially heard from Uqsuqtuurmiut, and see in diverse literature, is that Inuit generally do not distinguish between caribou herds. This impression may be why general references to caribou are most common when speaking with Inuit community members. Yet these discussions tend to be framed in relation to how scientists or managers distinguish caribou, and efforts to translate herd names between English and Inuktut. When inquiring further into Inuit approaches to naming and distinguishing caribou, we learned that various distinctions are made, which include the distinction between inland and island caribou (Table 1) and a number of other place, directional, and morphological references (Table 2). Through this effort to better understand Inuktut terminology and influences on caribou naming practices according to dialectical and geographic context, we came to realize the importance of acknowledging the historical and contemporary influences of traditional homelands and societies on how people come to know and relate to caribou. We began to see more clearly how naming reflects the interconnections between people and caribou, which are based on lived experience and intergenerational knowledge transfer. Uqsuqtuurmiut, and other Nunavummiut, were not explicitly stating this; but from our iterative efforts to understand, clarify, and share the names we present in this paper, we could start to see how the language used and places referred to are intimately tied to areas that Elders consider their homelands (Fig. 3).

\section{Language - Accounting for Dialect Differences}

Our review of caribou management reports and biological studies found that the herd most closely associated with Qikiqtaq (King William Island) is commonly known as the Ahiak herd (Ljubicic et al., 2017). The Ahiak herd was formerly known as the Queen Maud Gulf (QMG) herd, in reference to its calving grounds concentrated along the coastal areas of QMG (Ahiap Tariunga in Inuktitut). It was renamed with the Inuktitut word Ahiak in the early 1990s (Gunn et al., 2011; CARMA, 2013), although we could not find any discussion in the literature of which Inuktitut dialect this represents, from which community or region. The range of the Ahiak herd is rarely shown to extend onto Qikiqtaq itself, but its calving grounds along Ahiap Tariunga and seasonal presence on Iluiliq (the Adelaide Peninsula), as well as farther inland, suggest that it may be the herd most relevant to Uqsuqtuurmiut (Ljubicic et al., 2017).

When we asked specifically about the Ahiak herd during interviews and workshops in Uqsuqtuuq, the most common responses included shaking heads and puzzled looks. In a discussion that was part of WKSP (2013d), the hunters were not familiar with the name Ahiak and wanted to know where it came from. Their initial suggestion was that perhaps the Uqsuqtuurmiut Inuktitut dialect equivalent to Ahiak may be ijirak. Ijirait (plural) are "beings capable of transforming themselves into animals or humans," including caribou (Bennett and Rowley, 2004:440; also see Laugrand and Oosten, 2015). In both WKSP (2013d) and WKSP (2016a) Elders vividly described and shared their experiences with these "disappearing caribou," along with strong warnings that they are not to be hunted or eaten since their flesh disintegrates and it is dangerous to humans. However, this kind of unique caribou manifestation is clearly not the barren-ground caribou herd that biologists refer to as Ahiak.

In the Kingauk (Bathurst Inlet) region, Ahiarmiut is the name used to refer to mainland caribou (Thorpe et al., 2001a, b). While the -miut suffix can be used to refer to animals, as is the case for Qitirmiut that Thorpe worked with, it is most commonly used to denote "the people of (an area)" (Correll, 1976:173; Bennett and Rowley, 2004:443). Thus, references to Ahiarmiut as 'inland people' in relation to traditional homelands and hunting territories are common across Nunavut (Freeman, 1976; Bennett and Rowley, 2004; Collignon, 2006a; Laugrand and Oosten, 2015). However, without additional cultural or geographic context this reference can be confusing since there are several traditional inland societies known as Ahiarmiut (we use "societies" here as defined and used in Keith, 2004). Ahiarmiut profiled in Bennett and Rowley (2004) lived in the interior mainland west of Hudson Bay, and their territory bordered the tree line and Dene country (although there were several different Ahiarmiut societies living across the same region; also see Keith, 2004). Far to the northwest of Hudson Bay were two additional distinct 


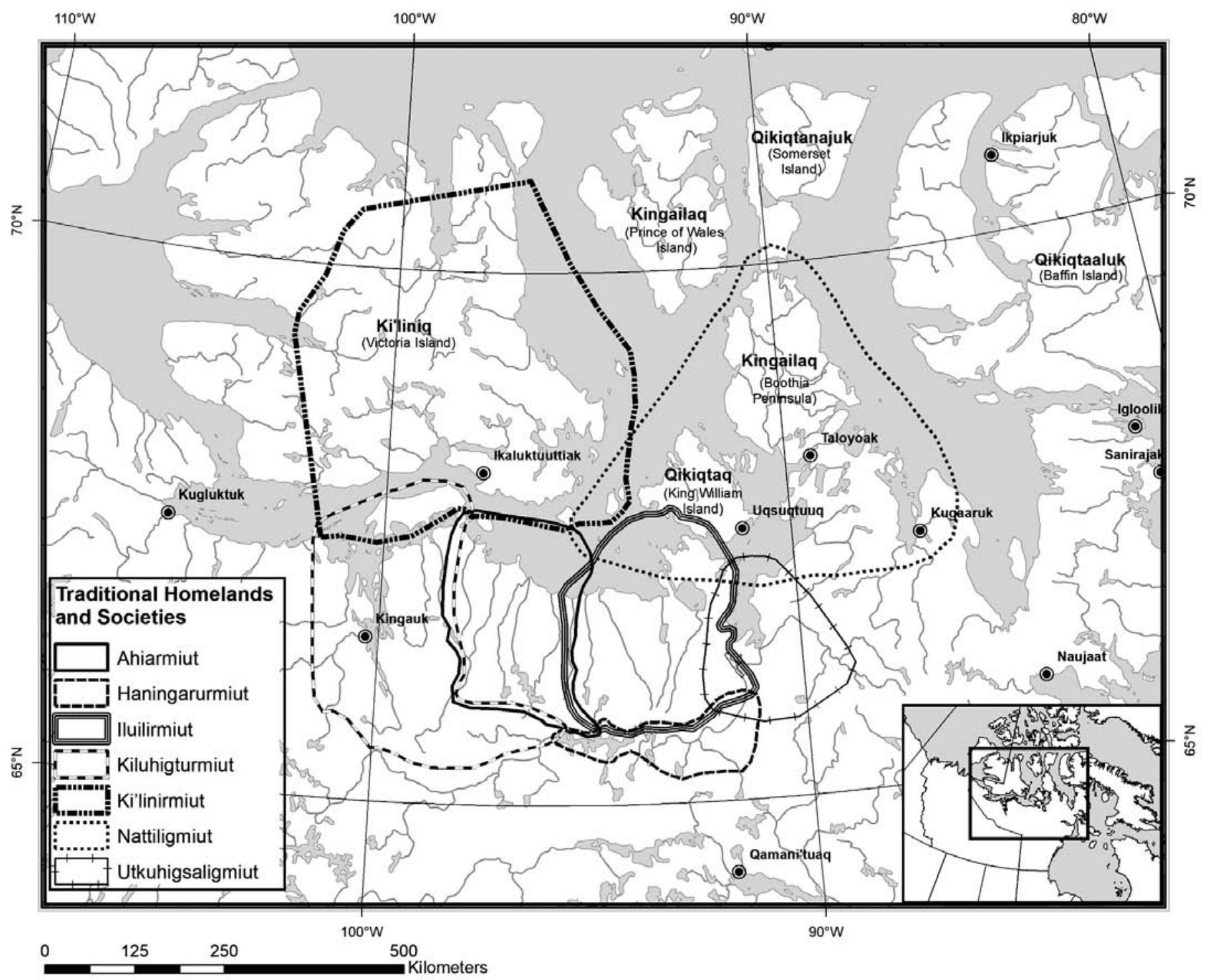

FIG. 3. Map showing the diversity of traditional homelands and societies of people now living in Uqsuqtuuq. Source: WKSP (2016b).

Ahiarmiut groups: one around Kuugruaq (Perry River) and Kuunajuk (Ellice River) (Fig. 3) and another farther west, close to present-day Kugluktuk (but distinct from Qurluqturmiut) (Farquharson, 1976; Bennett and Rowley, 2004). Every discussion of Ahiarmiut relates to people from inland areas, and thus the Ahiak herd name likely reflects this Inuktut 'inland' description. Ahiak is also the implied translation of the QMG coastal region in the name of the Queen Maud Gulf (Ahiak) Migratory Bird Sanctuary (ECCC, 2017), although Gunn et al. (2000a:22) also recognize Illiulik as the Inuktitut name for QMG. Most Uqsuqtuurmiut did not associate with the name Ahiak, since the reference to 'inland' in their dialect is iluiliq, and thus Iluilirmiut is the specific reference to the people who traditionally lived on the Adelaide Peninsula (BriceBennett, 1976; WKSP, 2016b) (Fig. 3). This meaning is also reflected in the Inuktitut name for inland caribou: iluiliup tuktuit.
Although referring to caribou in relation to the places they inhabit or move to and from is a common practice of Inuit communities, this ahiak and iluiliq example is an important illustration of the need to take Inuktut dialectical differences into account. Generally, Inuit are not distinguishing barren-ground herds of caribou, but rather broadly referring to caribou that come from inland (or the mainland, for communities located on islands). This fact has important implications for biologists, conservation officers, or researchers engaging with local hunters who require Inuktut-English translation. If someone is asking about the Ahiak herd, and interpreters translate this as "inland" or "mainland," then responses will relate to barren-ground herds but will likely not distinguish between them. In Uqsuqtuuq, for example, such a question may result in no response at all if the interpreter is unfamiliar with the herd name "Ahiak." If responses are then translated back into English using "Ahiak," it is likely that responses would be understood as relating specifically to the Ahiak herd when 
in fact the discussion was about barren-ground (inland) caribou in general. This potential mixing of references to specific herds instead of broad subspecies (or particular regions) may lead to misunderstandings that could have significant implications for broader management decisions. Some Inuit are quite familiar and used to working with herd categories defined in management plans according to biological conventions, often because of their experience in roles such as conservation officer, HTO manager or board member, wildlife co-management board member, research assistant as a caribou observer (during aerial surveys) or sampler (during on-the-ground surveys), or interpreter/ translator for diverse research projects. For example, Willie Aglukkaq (a former HTO manager) and Jacob Keanik (a former conservation officer) spoke of their involvement in various caribou surveys and were very familiar with biological herd names and distinctions. However, if the aim is to engage a diversity of Elders and hunters in better understanding, monitoring, and caring for caribou as part of co-management efforts, one cannot assume that conventional English herd names will be understood or even accepted in community contexts. For those communities increasingly engaged in developing locally led monitoring or guardianship programs, emphasis on local dialect and terminology is often an important starting point. Developing ways to communicate these distinctions to researchers or managers, and how they may or may not translate into English, could provide a foundation to begin influencing broader discussions and terminology used. Working with locally meaningful terms and understanding local approaches to naming and distinguishing caribou are thus imperative to facilitate communication and mutual understanding.

\section{Place - Understanding Relative Geographic References}

It has long been recognized that Inuit possess a depth and sophistication of geographic knowledge that accumulates over time through ways of knowing, being, and doing in life on the land (Correll, 1976; Ross, 1976; Nuttall, 1992; Aporta, 2004; Collignon, 2006a; Müller-Wille and Müller-Wille, 2006). This knowledge in action is integrated into social structures and Inuktut language and passed on through oral tradition (Collignon, 2006a). In this way, place names are "imbued with cultural information that is coded in their meanings...[they] function as mnemonics - archives of cultural knowledge to be read from the land" (Keith, 2004:40). Place names in particular have been an important emphasis for many collaborative efforts attempting to better understand Inuit geographic knowledge, as well as for asserting Inuit land rights (Freeman, 1976; Aporta, 2005; Collignon, 2006a; Müller-Wille and Müller-Wille, 2006). In work on Inuit toponymy, naming places is often described in the context of facilitating safe travel and wayfinding (Aporta and Higgs, 2005; Collignon, 2006b). Nuttall (1992) and Collignon (2006a) go farther, invoking the concept of "memoryscape" to convey the multidimensional nature of Inuit place names. Many places often have both a literal meaning (i.e., a description of the place) and a "real" meaning (i.e., one implied in relation to travel and use) and thus comprise a narrative of the land (Collignon, 2006b:197). Learning about the meanings of place names reveals more than physical descriptions of land or water features: it can provide a glimpse into the ways that particular Inuit societies perceive and experience their environment and organize and orient themselves within the landscape (Keith, 2004).

Given the cultural and narrative importance of place names, it comes as no surprise that Uqsuqtuurmiut frequently referred to particular places for hunting caribou, using specific place names to identify important lakes, rivers, camps, straits, peninsulas, inlets, islands, and other features. They also shared observations of the direction caribou were coming from or moving toward in relation to particular places or communities. For example, Akkikungnaq (2013), speaking in English, refers to a number of places in his description of caribou movements:

Okay. Caribous-I am going to use just Richardson Point. That's where I know the caribou is heading to and heading back out. Early in May the caribous moving from inland to King William Island usually go by Richardson Point...It goes that way in the springtime...I have never really studied them where they came from. What I know is where they came from is somewhere in that Garry Lake south and [they] move up [toward Queen Maud Gulf] to do calving...I never really have looked into it, but I do know that there is a different fatness from this area. The ones coming to King William Island, what they usually have in the past is that they were skinny. But the other ones coming from between here and say Kugaaruk and coming also from this area south [indicating on map], they are usually more meaty...[Other caribou come from the] Baker Lake area or Rankin [Inlet] area...What I do is I go across this channel here [indicating on map...gesturing towards Boothia Peninsula], and we usually do caribou hunting in this area.

As Aporta (2005:223) describes it, the Inuit method of geographic representation "is based on precise oral descriptions of the territory, where horizons are depicted as the speaker recalls them from actual travel, and named places and other features are called up as seen or imagined from particular standpoints." This description highlights the need to understand the reference points from which a speaker is telling a story (i.e., where the speaker is in the story). Many place names can be the same at the literal level (for example, naming a big island qikiqtarjuaq), and so the specific place being mentioned only becomes clear if you know the context of the story. It is beyond the scope of this paper to detail all the places discussed and their more nuanced Inuktut meanings, but we nevertheless wish to highlight the importance of engaging in such learning to 
better understand Inuit-caribou relationships. For example, Keith's (2004) work with Harvaqtuurmiut highlights how the importance of caribou migrations and crossings in seasonal hunting is reflected in the naming of places throughout their territory and indeed in how people in this society perceived the landscape and oriented themselves within it. What we want to stress here is the importance of recognizing the geographic context within which people are speaking. To illustrate this point, we discuss the example of "island" caribou and the implications of knowing the relative geographic context to understand how caribou are being distinguished.

In Inuit communities, as well as in the literature, references to "island caribou" are common. In Uqsuqtuuq, kingailaup tuktuit is a specific reference to caribou from Kingailaq (Prince of Wales Island), but it is often translated as "island caribou" and used to refer generally to Peary caribou occupying the islands of the Canadian Arctic Archipelago. With a slight spelling variation, COSEWIC (2004:8) also recognizes kingailik tuktu as meaning "Prince of Wales Island caribou," and throughout the assessment relates this name to Peary caribou, with specific reference to Taloyoak in a few places. However, some confusion arises when COSEWIC (2004:18) briefly mentions that Inuit and Inuvialuit recognize Dolphin and Union (DU) caribou as "Peary-type or island caribou as opposed to barren-ground or mainland caribou." In relation to King William Island, COSEWIC (2004:46) states that Inuit from Gjoa Haven recognize two types of caribou: "mainland caribou (i.e., barren-ground caribou) and Peary-type caribou that they believe cross over from Victoria Island (i.e., Dolphin and Union caribou)." So in COSEWIC (2004), kingailik tuktu is used in relation to Taloyoak on Boothia Peninsula, but is not connected with Gjoa Haven on King William Island (COSEWIC, 2004). In Thorpe et al. (2001a, b) Kiilliniq is used to refer to island caribou, yet around Kingauk (Bathurst Inlet), this reference relates to Victoria Island and thus to DU caribou. Similarly, Dumond (2007) uses "island caribou" synonymously with "DU caribou." In this case, the Inuktut terminology referring to "island" is likely mutually understood across dialects (see Fig. 1 where Ki'liniq is also the Uqsuqtuurmiut name for Victoria Island), but it is referring to different prominent "reference islands" depending on the community. In Uqsuqtuuq the "island" reference refers to Kingailaq (Prince of Wales Island) and Peary caribou, while in Kingauk it refers to Kiilliniq (Victoria Island) and DU caribou (i.e., to a distinct subspecies of caribou as characterized by biologists). Therefore, one must account for local cultural and geographic context to ensure that discussions of "island caribou" are indeed focused on the same type of caribou. Understanding the positional context of how a hunter is relaying a story is important to interpreting the knowledge that he or she is sharing. For example, a meeting may be held in Uqsuqtuuq, but if a hunter is talking about an experience from a traditional camp around Kuugruaq (Perry River) much farther west, the "island" reference may be to DU caribou and not Peary caribou, as would be more common with those who are originally from Iluiliq (Adelaide Peninsula) or Utkuhigsaliup Kuunga (Back River).

When we consider the various references to a possible "mixed breed" of mainland and island caribou, the island caribou terminology becomes increasingly confusing and contradictory. Herd mixing and range overlap were commonly described by Uqsuqtuurmiut, as well as by other Qitirmiut (Thorpe et al., 2001a). For example, George Kavanna is cited in Thorpe et al. (2001b:87) as describing a mix of island and mainland caribou and referring to them as Kiilliniq. Kiilliniq and Bathurst herds were also described as mixing to become the Queen Maud Gulf (Ahiak) herd (Thorpe et al., 2001a). Throughout Thorpe et al. (2001a), the term Kiilliniq is specifically linked to Victoria Island, although in the table of Inuinnaqtun names it is more generically translated as "island caribou" (Thorpe et al., 2001a:34). So Kiilliniq is generally associated with DU caribou in English, but Qitirmiut descriptions also consider this to be a mixture of island and mainland caribou. In Uqsuqtuuq, Arqviq (2012), Carter (2012), and Sallerina (2012) described kingailaup tuktuit (island caribou) and iluiliup tuktuit (inland caribou) mixing to create a new type of caribou crossbreed, and this phenomenon was further discussed in WKSP (2013b). However, no distinct Inuktitut name was suggested for this "mixed breed," and there was no clear consensus on this type of caribou in the community (WKSP, 2016a). In further discussion, Okpakok clarified that mixed caribou are considered very rare, as uncommon as seeing a pukiq (albino caribou). They exist, but have rarely been seen, so not many hunters would have had this experience. This mixing of herds is also considered a more recent phenomenon. Indeed, iluiliup tuktuit were not present on Qikiqtaq from around the 1930s to the mid1980s (Ljubicic et al., in press), which may partially explain why Elders today were not familiar with this kind of mixed caribou. In their earlier years, Elders traveled extensively across the region, but at that time caribou were more spread out and were not crossing onto Qikiqtaq. Today there is more contact between the two types of caribou, so the younger generation of hunters could be seeing a new "mixed breed" that may not have existed in the past. Bringing clarity to the matter would require more detailed discussion and further investigation to fully understand the nuances at play.

Efforts to understand these island caribou references are further complicated by references in the literature to "Arctic-island caribou," which seem to be distinguished from Peary, DU, and barren-ground caribou. Caribou north of $74^{\circ} \mathrm{N}$ latitude in the Queen Elizabeth Islands (QEI) are characterized as Peary caribou, while those on the southern Arctic islands (Banks, Victoria, Somerset, and Prince of Wales Islands, and some on Boothia Peninsula) are "Arcticisland caribou" (Miller, 1990 cited in Gunn et al., 2000b). Arctic-island caribou are also described as smaller than barren-ground caribou, but larger than Peary caribou. Arctic-island caribou references are usually made in 
relation to studies focused on Prince of Wales and Somerset Islands (Thomas and Everson, 1982; Røed et al., 1986; Gunn and Dragon, 1998; Gunn et al., 2000b; COSEWIC, 2004), although they are also discussed in relation to Banks Island, Victoria Island, King William Island, and Boothia Peninsula (Gunn and Dragon, 1998; Gunn et al., 2000b; Sly et al., 2001; Miller et al., 2007; WKSSS, 2008). The term "Arctic-island caribou" is also used in relation to Victoria Island, referring to the DU herd (Gunn et al., 2000a; Nishi and Gunn, 2004) and the Minto Inlet herd (Nishi and Buckland, 2000; Nishi and Gunn, 2004). The use of Arcticisland caribou terminology varies within the literature, and there are uncertainties among Inuit about distinguishing a new type of mixed caribou based on observations of herd mixing. Perhaps Inuktitut descriptions of kingailaup tuktuit as being small, white caribou are not even referring to Peary, but rather to Arctic-island caribou occupying the southern QEI, where hunters in the Kitikmeot region would most commonly be traveling, rather than the High Arctic islands. Miller et al. (2007:244) even suggest that "Inuit hunters prefer the meat of Arctic-island caribou to that of either the Boothia Peninsula ecotype or the Mainland ecotype," although this point was not raised by the Uqsuqtuurmiut we worked with. These multi-layered terminology considerations suggest the need to carefully define how "island caribou" is being used in a given context and emphasize that further investigation is warranted from both Inuit and biological perspectives to clarify whether "Arctic-island caribou" is indeed a distinct and relevant categorization.

\section{Homeland - Recognizing Influences of Traditional Territories and Societies}

The intertwined elements of language and place emphasized above show how Inuit approaches to naming and distinguishing caribou are intimately connected with individual land-based knowledge and hunting experience, as well as particular family and social networks. As we noted in the introduction, caribou are embedded in Inuit life and culture. The movements of traditional Inuit societies have long been tied to the seasonal rounds of caribou, and these connections remain strong today in relation to hunting practices, physical and mental health, cultural values and identity, and inter-generational learning. To understand places and regions referred to in hunting or travel stories means that the listeners need to be familiar with the regions, local dialects, and meanings of place names so as to interpret the richness of landscape, way-finding, and other information provided in the narrative. Elders especially would emphasize the camp names of places they grew up and the areas they traveled in their younger years. Their personal knowledge and experience are directly tied to these areas, and their identities and spoken dialects of Inuktut are still strongly defined by this connection. "People felt that they belonged to the land and named themselves accordingly. Each regional group referred to themselves as the -miut (people) of that region" (Bennett and Rowley, 2004:120). This -miut suffix continues to be relevant as an indicator of Inuit cultural and family ties, as well as the traditional territories that people inhabit(ed). Indeed Inuktut dialect (and accent) is one of the primary aspects used to distinguish -miut groups. Other aspects are identification with a certain general territory; identification in some way (through kinship, alliances, or partnerships) with all members of a group of several small camps or settlements that are dispersed and vary with seasonal activities (Correll, 1976; Keith, 2004); and distinctive patterns or decorative designs in traditional skin clothing (Keith, 2004; WKSP, 2016b). Therefore, being aware of the -miut group(s) that people identify with is an important step toward understanding linguistic and geographical contexts.

Nunaqatigiit literally means 'the people who live together at a place,' but Correll (1976:174) also uses the term metaphorically to refer to "dwelling in the world through language." We feel that this eloquent metaphor encapsulates the arguments we are trying to convey here. Language and place are related within Inuit cultural contexts, contributing to a sense of belonging that is connected to traditional homelands and societies. Elders continue to identify as being part of a particular -miut group, and they discuss their experiences of caribou hunting in relation to these regions in both historical and current contexts. It is important to recognize that Elders living in Uqsuqtuuq today represent a diversity of traditional societies (Fig. 3) (WKSP, 2016b):

Nattiligmiut - people of the seal, from around present-day Taloyoak

Iluilirmiut - people from the mainland (inland), around Iluiliq, the Adelaide Peninsula and Aimmatquttak (Sherman Basin) area

Utkuhigsaligmiut - people from the area near the mouth of Utkuhigsaliup Kuunga (the Back River)

Ahiarmiut - people from the mainland, from around the western Ahiap Tariunga (Queen Maud Gulf) area, near Kuugruaq (Perry River) and Kuunajuk (Ellice River)

Haningarurmiut - people from around the Kangiq\&ugruaq (Garry Lake) area

Kiluhigturmiut - people from around the Kingauk (Bathurst Inlet) and Kent Peninsula (no local Inuktitut name) area

Ki'linirmiut - people from Ki'liniq (Victoria Island) and the mainland area west of Kingauk (Bathurst Inlet) to Kugluktuk.

These traditional homelands continue to frame people's diverse experiences with and knowledge of caribou.

Inuit living in Uqsuqtuuq today may call themselves Uqsuqtuurmiut (people of Uqsuqtuuq), but this is a relatively recent designation related to the establishment of Gjoa Haven as a permanent settlement. It is important to recognize the diversity that exists within the community because it relates to community dynamics. Inuit from 
different traditional societies now live together in Uqsuqtuuq, and many families continue to identify with the homelands where they or their Elders grew up. In Uqsuqtuuq today, there is a very small number of Utkuhigsaligmiut, a larger proportion of Iluilirmiut, a small number of Nattiligmiut, and small number of Ki'linirmiut, distinguished according to Inuktitut dialect, accent, and family networks. These -miut group identities may be more directly relevant to studies with a historical focus, but they are still important to understand today as they provide the context for language and places used to describe caribou (not to mention family networks and histories). These traditional homelands and societies also remain relevant for younger generations since their Elders and family members tend to return to the areas they are most familiar with, and their preferred hunting areas are often tied to former seasonal rounds. So Uqsuqtuurmiut are still likely to be more connected to regions occupied by their grandparents' -miut group than to other areas, although this connection certainly does not limit people's experiences or where they may choose to travel or hunt. Puqiqnak (2012) identifies himself as Utkuhigsaligmiut from where he grew up, but marrying a Nattiligmiut woman means his children identify with - and experience-connections with both groups:

I call myself Utkuhigsaligmiut...from this area [indicating on map around Back River]. It means that we're not from this area [around Gjoa Haven]. We're not from this area but we moved to this area... People from this area call themselves Iluilirmiut... but my people, people from this area [Back River], all my sisters and brothers and people from there, they are Utkuhigsaligmiut...So my children is a half of the Utkuhigsaligmiut, and because I married [a] Nattiligmiut...sometimes people call our children half of the Utkuhigsalik half of the Nattilik.

So while middle-aged or younger hunters may not identify as closely with a particular -miut group if they did not grow up on the land, they are still connected to these areas through kinship, oral histories, and experiences (e.g., where they travel and hunt with their family). While current use areas may be contracted compared to the extensive travel that was needed for survival in a traditional nomadic lifestyle, these areas remain important today and influence the daily practice of travel and hunting across Nunavut. For Inuit knowledge of caribou to be better reflected in caribou management strategies, we thus argue for more attention to language and place in the context of caribou discussions, as well as for greater recognition of how these factors are tied to areas used seasonally for caribou hunting (Ljubicic et al., in press). Understanding more of the seasonal extent and variability of these important use areas around each community will increase our potential to explore how these areas are connected to - and may help to conceptualizecaribou health, behaviour, and movements across caribou ranges.

\section{CONCLUDING THOUGHTS}

What we learned in Uqsuqtuuq, and what seems to be closely mirrored across the Kitikmeot and Kivalliq regions of Nunavut, is that caribou are caribou. Inuit do not place great emphasis on distinguishing caribou herds, at least not in the way that biologists or managers do. However, this is not the full story. As we pay attention to context shared through language, place, and homeland, a richer understanding of Inuit knowledge of caribou emerges. Inuit approaches to naming and distinguishing caribou are about where and how people are engaging with caribou, which is intimately connected to traditional homelands, important places, and seasonal hunting areas. These areas are where the most extensive experience and engagement with caribou exist, which is reflected in associated dialectical and geographic terminology as well as in cultural identity. Therefore, it is not so much about naming and defining herds according to their full seasonal ranges: it is about naming caribou in relation to hunting practices in particular places at particular times of year. For Inuit, in other words, caribou references emphasize the relationship people have with caribou rather than the caribou alone. This relationship is central in co-management efforts that seek to recognize, respect, and incorporate Inuit knowledge into all aspects of decision making. In support of the GN's (2011) Inuillu Tuktuillu (people and caribou) objective, we suggest that further consideration of Inuit approaches to naming and distinguishing caribou could contribute to grounding management discussions and decisions in local dialect and geographic context, accounting for both traditional and contemporary uses of caribou.

In caribou management plans, biological classifications and herd range maps are the foundation for geographic representations, survey and assessment protocols, and ultimately, the framing of management decisions. Many of the herd names (e.g., Bathurst, Beverly, Qamanirjuaq, Wager, Lorillard) reflect important places as the means of defining the herd, usually representing the central areas used for calving grounds. These names are then used when discussing the full geographic extent of a herd range, or assessing population status, with genetic and morphological distinctions used to support these delineations. However, when using these same names in the context of community meetings, or seeking insights from Inuit knowledge, we must be aware of how translated herd names may be taken as either local references (i.e., as caribou around specific places rather than the full regional extent of the herd) or broader references to a subspecies and not a particular herd. Either way, the responses elicited may not be addressing the same scale or herd conceptualizations that biologists are working from, and this mismatch could result in misunderstandings or misinterpretations. This emphasis on translation and being familiar with underlying meanings highlights the critical importance of communication and mutual understanding as the foundation of effective 
knowledge-sharing to inform representative and meaningful decision making.

Inuit who have been a part of co-management efforts or caribou surveys are well accustomed to herd names used by biologists and decision makers. They may be quite comfortable with these formal caribou classifications and also adept at switching back and forth using appropriate names in a management context (English) or in a local hunting context (Inuktut). However, those on the management or research side, or who are relative newcomers to northern caribou management, may not be quite so conversant in both contexts. Our experiences in Uqsuqtuuq and review of the approaches to naming and distinguishing caribou across the Kitikmeot and Kivalliq regions suggest several considerations that could contribute to improved communications in support of mutual understanding:

- begin caribou research or management discussions with dialogue about local approaches to naming and distinguishing caribou and the appropriate local Inuktut terms, in an effort to clarify whether or how these terms relate to biological herd classifications;

- work closely with interpreters ahead of meetings to encourage the use of local terminology and to learn the meaning of the literal translations to avoid defaulting to the use of biological herd names that may or may not be understood or accepted in a community context;

- become acquainted with local geographies and important place name references that people relate to caribou hunting, migrations, calving, rutting, food (vegetation), crossings, and refuge areas; and

- become familiar with traditional homelands and societies reflected in -miut identity and how these relate to current dialectical differences, community diversity, and different use areas reflected in contemporary hunting practices and regions.

We acknowledge, however, that these are not easy things to do. The kinds of information needed to gain this level of contextual familiarity are not readily accessible to the public. It often takes years of initial collaboration to understand local cultural and geographic context before being able to support more in-depth discussions. Many biologists and managers are already doing this and have developed tremendous sensitivity and understanding over years of working with HTOs and local hunters. However, these efforts are not clearly reflected in the terminology or maps presented in most management documents or government reports. It is even less evident how different ways that people (e.g., a visiting researcher, a biologist living in a community, an Inuk hunter) relate to caribou can influence the development of relationships, trust, and communication in the co-management process and the decisions made. Highlighting these connections more effectively in co-management plans and public reportsbeginning with terminology and geographic context and moving toward more relational context over time-would be a valuable step forward in collective efforts to incorporate and learn from Inuit knowledge. Indeed, such efforts could create enhanced possibilities for understanding how caribou support important material aspects of community life (e.g., food, clothing, economic activities, physical health); learning about the role of caribou in social and intergenerational relationships involving cultural values and skills, piquhiit (rules to be followed), food sharing, celebrations, spirituality, oral histories, and mental health; and representing the diversity of community contributions to Inuit knowledge research (Kendrick, 2000; Thorpe et al., 2001a, b; Natcher and Hickey, 2002; Cruikshank, 2004; Thorpe, 2004; Natcher et al., 2005; Nadasdy, 2007; GN, 2011; Laugrand and Oosten, 2015).

Since caribou health and habitat monitoring are so closely tied to how herds are defined in current management approaches, considerations identified in this paper have broader implications beyond communication and respectful relationships in co-management. We propose that there may be value in engaging in more systematic efforts to delineate key regional harvesting areas that reflect the terminology, important places, and connections to traditional homelands that influence caribou hunting practices. These efforts could produce something similar to the hunting regions of Ferguson et al. (1998), which were derived from participatory mapping sessions with hunters and discussing caribou distribution and abundance over time in southern Qikiqtaaluk (Baffin Island). These areas were defined by regional place names (e.g., Foxe Peninsula, Nettling Lake, Tassialukjuaq) and represented overlapping use areas or collective hunting practices from multiple communities. A similar definition of regional use areas could contribute to developing longer-term monitoring and caribou management efforts that are grounded in peoples' connections with caribou. Such regional delineations would complement ongoing population-scale surveys and assessments and might encourage greater hunter engagement or leadership in community-based monitoring initiatives if more closely tied to locally important caribou habitat and hunting areas. Learning from and building on efforts in other regions (e.g., Moller et al., 2004; Natcher and Hickey, 2002; Lyver and Lutsel K'e Dene First Nation, 2005; Parlee et al., 2005; TG, 2008; Brook et al., 2009; Russell et al., 2013; Polfus et al., 2016; SRRB, 2016), delineating regional use areas could help identify spatial and conceptual areas where community and management priorities intersect. Such an approach could also begin to address the lack of baseline information, especially in relation to available and documented local and Inuit knowledge, and contribute to community-based caribou monitoring activities in Nunavut (GN, 2011; BQCMB, 2014). In this process, enhanced sensitivity to language and to geographic and cultural context can support more balanced consideration of knowledge systems and diverse experiences with caribou, and work toward fulfilling the spirit of co-management. 


\section{ACKNOWLEDGEMENTS}

We are grateful to Uqsuqtuurmiut who contributed their time, guidance, and insights to this project over the past six years, through early planning meetings, interviews, land camps, and verification workshops. We thank the Kitikmeot Inuit Association, the Elders' Qaggivik, the Hamlet of Gjoa Haven, Qiqirtaq High School, Tahiurtiit (Justice) Committee, the Hunters and Trappers Association, the District Education Authority, the Nattilik Heritage Centre, and the Government of Nunavut for critical in-kind and logistical support. We also extend our thanks to Stephanie Pyne, for interview transcription and reference support; to Glenda Smith, for creating the base maps used in participatory mapping and for digitizing the results; and to Alex de Paiva, for creating the compilation maps used in the figures in this paper. Thanks also to Erik Val for facilitating the September 2016 verification workshop discussion on place names and traditional homelands and societies, as well as for helpful feedback as we refined our analysis. We also thank Darren Keith for providing valuable feedback on early versions of this paper and for his help in verifying place names. We thank three anonymous reviewers for their thoughtful and constructive comments that helped to refine and strengthen our paper. We are grateful to the Social Sciences and Humanities Research Council for supporting this project through a Research Development Initiative grant and then a Standard Grant. The Northern Scientific Training Program, the Nasivvik Centre for Inuit Health and Changing Environments, the Gordon Robertson Scholarship (Carleton University), and the Alain Maktar Heritage Scholarship (Inuit Heritage Trust) funding provided important travel and financial support for Rebecca Mearns during her master's degree research. Additional funding was provided by Carleton University to Gita Ljubicic and by the University of Alberta to Sean Robertson. Our work was undertaken under Nunavut Scientific Research License \#04 058 12N-M and Carleton University ethics protocol approval 12-1439.

\section{REFERENCES}

Aaluk, P. 2012. Interview in Gjoa Haven, Nunavut. Interviewed by S. Robertson; interpreted by L. Aaluk, 22 August 2012.

ACCWM (Advisory Committee for Cooperation on Wildlife Management). 2014. "We have been living with the caribou all our lives...": A report on information recorded during community meetings for 'Taking Care of Caribou - the Cape Bathurst, Bluenose-West, and Bluenose-East Barren-Ground Caribou Herds Management Plan.' Yellowknife: ACCWM.

Adamczewski, J., Gunn, A., Poole, K.G., Hall, A., Nishi, J., and Boulanger, J. 2015. What happened to the Beverly caribou herd after 1994? Arctic 68(4):407-421.

https://doi.org/10.14430/arctic4523

Aglukkaq, W. 2012. Interview in Gjoa Haven, Nunavut. Interviewed by S. Robertson, 27 July 2012.

Akkikungnaq, P. 2013. Interview in Gjoa Haven, Nunavut. Interviewed by S. Robertson, 24 July 2013.
Akoak, J. 2012. Interview in Gjoa Haven, Nunavut. Interviewed by R. Mearns and S. Robertson; interpreted by R. Mearns, 16 August 2012.

Aporta, C. 2004. Routes, trails and tracks: Trail breaking among the Inuit of Igloolik. Études/Inuit/Studies 28(2):9-38. https://doi.org/10.7202/013194ar

- 2005. From map to horizon; from trail to journey: Documenting Inuit geographic knowledge. Études/Inuit/ Studies 29(1-2):221-231. https://doi.org/10.7202/013941ar

- 2009. The trail as home: Inuit and their pan-Arctic network of routes. Human Ecology 37(2):131 - 146. https://oi.org/10.1007/s10745-009-9213-x

Aporta, C., and Higgs, E. 2005. Satellite culture: Global positioning systems, Inuit wayfinding, and the need for a new account of technology. Current Anthropology 46(5):729-753.

Aqslaluk, S. 2013. Interview in Gjoa Haven, Nunavut. Interviewed by S. Robertson; interpreted by S. Okpakok, 19 July 2013.

Arqviq, J. 2012. Interview in Gjoa Haven, Nunavut. Interviewed by R. Mearns and S. Robertson, 15 August 2012.

Atkichok, J. 2012. Interview in Gjoa Haven, Nunavut. Interviewed by R. Mearns and S. Robertson; interpreted by S. Okpakok, 26 July 2012.

Atkichok, M. 2013. Interview in Gjoa Haven, Nunavut. Interviewed by S. Robertson; interpreted by L. Aaluk, 24 July 2013.

Bayha, W. 2012. Using Indigenous stories in caribou comanagement. Rangifer 32(Special Issue No. 20):25-29. https://doi.org/10.7557/2.32.2.2241

Bennett, J., and Rowley, S., comp. and eds. 2004. Uqalurait: An oral history of Nunavut. Montreal and Kingston: McGillQueen's University Press.

Bennett, K. 2002. Interviews and focus groups. In: ShurmerSmith, P., eds. Doing cultural geography. London: SAGE Publications Ltd. 151-164.

https://doi.org/10.4135/9781446219706.n14

Berkes, F. 2009. Evolution of co-management: Role of knowledge generation, bridging organizations and social learning. Journal of Environmental Management 90(5):1692 - 1702.

https://doi.org/10.1016/j.jenvman.2008.12.001

BQCMB (Beverly and Qamanirjuaq Caribou Management Board). 1996. Beverly and Qamanirjuaq caribou management plan: 1996-2002. Ottawa: BQCMB.

- 2014. Beverly and Qamanirjuaq caribou management plan: 2013-2022. Stonewall: BQCMB.

Brice-Bennett, C. 1976. Inuit land use in the east-central Canadian Arctic: Gjoa Haven. In: Freeman, M.M.R., ed. Inuit land use and occupancy project, Vol. 1: Land use and occupancy. Ottawa: Department of Indian and Northern Affairs. 76-81.

Brook, R.K., Kutz, S.J., Veitch, A.M., Popko, R.A., Elkin, B.T., and Guthrie, G. 2009. Fostering community-based wildlife health monitoring and research in the Canadian North. EcoHealth 6(2):266-278. https://doi.org/10.1007/s10393-009-0256-7 
CARMA (CircumArctic Rangifer Monitoring and Assessment Network). 2013. Ahiak/Beverly. Akureyri, Iceland: Conservation of Arctic Flora and Fauna (CAFF).

http://carma.caff.is/index.php/herds/538-carma/herds/556ahiak

Carter, T. 2012. Interview in Gjoa Haven, Nunavut. Interviewed by S. Robertson, 3 August 2012.

CLEY (Department of Culture, Language, Elders and Youth). 2017. Inuktitut Living Dictionary. Iqaluit: CLEY, Government of Nunavut.

http://www.livingdictionary.com (no longer available).

Collignon, B. 2006a. Knowing places: The Inuinnait, landscapes and the environment. Edmonton: Canadian Circumpolar Institute Press.

2006b. Inuit place names and sense of place. In: Stern, P., and Stevenson, L., eds. Critical Inuit studies: An anthology of contemporary Arctic ethnography. Lincoln: University of Nebraska Press. 187-205.

Collings, P. 1997. Subsistence hunting and wildlife management in the central Canadian Arctic. Arctic Anthropology 34(1):41-56.

Correll, T.C. 1976. Language and location in traditional Inuit societies. In: Freeman, M.M.R., ed. Inuit land use and occupancy project, Vol. 2: Supporting studies. Ottawa: Department of Indian and Northern Affairs. 173-179.

COSEWIC (Committee on the Status of Endangered Wildlife in Canada). 2004. Peary caribou Rangifer tarandus pearyi and barren-ground caribou Rangifer tarandus groenlandicus, Dolphin and Union population in Canada. COSEWIC Assessment and Update Status Report. Ottawa: COSEWIC.

- 2016. COSEWIC assessment and status report on the caribou Rangifer tarandus, barren-ground population in Canada. Ottawa: COSEWIC.

Cruikshank, J. 2004. Uses and abuses of 'traditional knowledge': Perspectives from the Yukon Territory. In: Anderson, D.G., and Nuttall, M., eds. Cultivating Arctic landscapes: Knowing and managing animals in the circumpolar North. London: Berghahn Books. 17-32.

Dumond, M. 2007. Western Kitikmeot caribou workshop. Final Wildlife Report No. 19. Kugluktuk: Department of Environment, Government of Nunavut.

Dumond, M., Sather, S., and Harmer, R. 2013. Observation of Arctic island barren-ground caribou (Rangifer tarandus groenlandicus) migratory movement delay due to human induced sea-ice breaking. Rangifer 33(Special Issue No. 21):115-121.

https://doi.org/10.7557/2.33.2.2533

ECCC (Environment and Climate Change Canada). 2017. Queen Maud Gulf (Ahiak) Migratory Bird Sanctuary. Ottawa: ECCC. https://www.ec.gc.ca/ap-pa/default.asp?lang=En\&n=20CAE $357-1$.

Eleehetook, P. 2012. Interview in Gjoa Haven, Nunavut. Interviewed by S. Robertson; interpreted by L. Aaluk, 22 August 2012.

Eleehetook, R. 2013. Interview in Gjoa Haven, Nunavut. Interviewed by S. Robertson; interpreted by S. Okpakok, 19 July 2013.
Farquharson, D.R. 1976. Inuit land use in the west-central Canadian Arctic: Cambridge Bay. In: Freeman, M.M.R., ed. Inuit land use and occupancy project, Vol. 1: Land use and occupancy. Ottawa: Department of Indian and Northern Affairs. 42-49.

Ferguson, M.A.D., Williamson, R.G., and Messier, F. 1998. Inuit knowledge of long-term changes in a population of Arctic tundra caribou. Arctic 51(3):201-219.

https://doi.org/10.14430/arctic1062

Fisher, J.T., Roy, L.D., and Hiltz, M. 2009. Barren-ground caribou management in the Northwest Territories: An independent peer review. Vegreville: Alberta Research Council, Sustainable Ecosystems Unit, Ecological Conservation Management Program.

http://www.enr.gov.nt.ca/sites/enr/files/reports/arc_nwt caribou_review_january_2009.pdf

Fox, S. 2002. These are things that are really happening: Inuit perspectives on the evidence and impacts of climate change in Nunavut. In: Krupnik, I., and Jolly, D., eds. The earth is faster now: Indigenous observations of Arctic environmental change. Fairbanks: Arctic Research Consortium of the United States in cooperation with the Arctic Studies Center, Smithsonian Institution. $12-53$.

Freeman, M.M.R., ed. 1976. Inuit land use and occupancy project, 3 vols. Ottawa: Department of Indian and Northern Affairs.

GC (Government of Canada) and TFN (Tunngavik Federation of Nunavut). 1993. Agreement Between the Inuit of the Nunavut Settlement Area and Her Majesty the Queen in Right of Canada. Iqaluit: GC and TFN.

GN (Government of Nunavut). 2007. Recommendations on total allowable harvest (TAH) rates for the terrestrial wildlife populations in Nunavut. Final Wildlife Report No. 4. Igloolik: Wildlife Research Section, Department of Environment, GN.

. 2011. Working together for caribou: Nunavut caribou strategy. Iqaluit: Department of Environment, GN.

- 2013. Incorporating Inuit societal values. Iqaluit: GN.

. 2015. HTO consultations on caribou issues in the Kitikmeot Region - Bathurst and Bluenose East caribou. Iqaluit: Department of Environment, GN.

GNWT (Government of the Northwest Territories). 2011. Caribou forever - our heritage, our responsibility: A barren-ground caribou management strategy for the Northwest Territories 2011-2015. Yellowknife: Department of Environment and Natural Resources, GNWT.

Gunn, A., and D'Hont, A. 2002. Extent of calving for the Bathurst and Ahiak caribou herds June 2002. Manuscript Report No. 149. Yellowknife: Department of Resources, Wildlife and Economic Development, Government of the Northwest Territories.

Gunn, A., and Dragon, J. 1998. Status of caribou and muskox populations within the Prince of Wales Island-Somerset Island-Boothia Peninsula complex, NWT, July-August 1995. File Report No. 122. Yellowknife: Department of Resources, Wildlife and Economic Development, Government of the Northwest Territories. 
Gunn, A., and Fournier, B. 2000. Caribou herd delimitation and seasonal movements based on satellite telemetry on Victoria Island 1987-89. File Report No. 125. Yellowknife: Department of Resources, Wildlife and Economic Development, Government of the Northwest Territories.

Gunn, A., and Miller, F.L. 1986. Traditional behaviour and fidelity to caribou calving grounds by barren-ground caribou. Rangifer 6(Special Issue No. 1):151-158. https://doi.org/10.7557/2.6.2.640

Gunn, A., Buchan, A., Fournier, B., and Nishi, J. 1997. Victoria Island caribou migrations across Dolphin and Union Strait and Coronation Gulf from the mainland coast, 1976-94. Yellowknife: Department of Resources, Wildlife and Economic Development, Government of the Northwest Territories.

Gunn, A., Fournier, B., and Nishi, J. 2000a. Abundance and distribution of the Queen Maud Gulf caribou herd, 1986-98. File Report No. 126. Yellowknife: Department of Resources, Wildlife and Economic Development, Government of the Northwest Territories.

Gunn, A., Miller, F.L., and Nishi, J. 2000b. Status of endangered and threatened caribou on Canada's Arctic islands. Rangifer 20(Special Issue No. 12):39-50. https://doi.org/10.7557/2.20.5.1623

Gunn, A., Russell, D., and Eamer, J. 2011. Northern caribou population trends in Canada. Canadian Biodiversity: Ecosystem Status and Trends 2010. Technical Thematic Report No. 10. Ottawa: Canadian Councils of Resource Ministers.

Hiqiniq, J. 2012. Interview in Gjoa Haven, Nunavut. Interviewed by R. Mearns and S. Robertson; interpreted by S. Okpakok, 27 July 2012.

Huntington, H.P. 1998. Observations on the utility of the semidirective interview for documenting traditional ecological knowledge. Arctic 51(3):237-242. https://doi.org/10.14430/arctic1065

Huntington, H.P., Brown-Schwalenberg, P.K., Frost, K.J., Fernandez-Giminez, M.E., Norton, D.W., and Rosenberg, D.H. 2002. Observations on the workshop as a means of improving communication between holders of traditional and scientific knowledge. Environmental Management 30(6):778-792.

InterGroup Consultants Ltd. 2008. Economic valuation and sociocultural perspectives of the estimated harvest of the Beverly and Qamanirjuaq caribou herds. Stonewall, Manitoba: Beverly and Qamanirjuaq Caribou Management Board.

Kamamalik, P. 2013. Interview in Gjoa Haven, Nunavut. Interviewed by S. Robertson; interpreted by L. Aaluk, 25 July 2013.

Keanik, J. 2012. Interview in Gjoa Haven, Nunavut. Interviewed by S. Robertson, 29 July 2012.

Keith, D. 2004. Caribou, river and ocean: Harvaqtuurmiut landscape organization and orientation. Études/Inuit/Studies 28(2):39-56. https://doi.org/10.7202/013195ar

Kendrick, A. 2000. Community perceptions of the BeverlyQamanirjuaq Caribou Management Board. Canadian Journal of Native Studies 20(1):1-33.
2002. Caribou co-management: Realizing conceptual differences. Rangifer 22(Special Issue No. 13):7-13. https://doi.org/10.7557/2.22.4.1655

- 2003. Caribou co-management and cross-cultural knowledge sharing. $\mathrm{PhD}$ thesis, University of Manitoba, Winnipeg, Manitoba.

Kendrick, A., and Manseau, M. 2008. Representing traditional knowledge: Resource management and Inuit knowledge of barren-ground caribou. Society \& Natural Resources 21(5):404-418.

https://doi.org/10.1080/08941920801898341

Kenny, T.-A., and Chan, H. 2017. Estimating wildlife harvest based on reported consumption by Inuit in the Canadian Arctic. Arctic 70(1):1-12.

https://doi.org/10.14430/arctic4625

Kofinas, G.P. 2005. Caribou hunters and researchers at the comanagement interface: Emergent dilemmas and the dynamics of legitimacy in power sharing. Anthropologica 47(2):179-196.

Konana, B. 2012. Interview in Gjoa Haven, Nunavut. Interviewed by R. Mearns and S. Robertson; interpreted by L. Aaluk, 14 August 2012.

Laidler, G.J., and Grimwood, B. 2010. Report on the results of a research planning workshop in Gjoa Haven: Qanuittumik takuvit? Workshop held from February 17-19, Gjoa Haven, Nunavut.

http://www.straightupnorth.ca/Sikuliriji/GH-SummReports. html

Laidler, G.J., Hirose, T., Kapfer, M., Ikummaq, T., Joamie, E., and Elee, P. 2011. Evaluating the Floe Edge Service: How well can SAR imagery address Inuit community concerns around sea ice change and travel safety? The Canadian Geographer 55(1):91- 107. https://doi.org/10.1111/j.1541-0064.2010.00347.x

Laugrand, F., and Oosten, J. 2015. Hunters, predators and prey: Inuit perceptions of animals. Oxford: Berghahn Books.

Ljubicic, G., Robertson, S., Mearns, R., and Okpakok, S. 2016. Results summary report for community organizations and contributors for the project "Connecting Inuit Elders and Youth: Learning about caribou, community, and well-being in Gjoa Haven, Nunavut (2011-2016).” Ottawa, Ontario and Gjoa Haven, Nunavut.

http://www.straightupnorth.ca/Sikuliriji/GH-SummReports. html

Ljubicic, G., Oberndorfer, E., and Smith, G. 2017. The curious case of King William Island, Nunavut: An island overlooked in caribou research. Arctic 70(1):107-117.

https://doi.org/10.14430/arctic4638

Ljubicic, G., Okpakok, S., Robertson, S., and Mearns, R. In press. Uqsuqtuurmiut inuita tuktumi qaujimanignit (Inuit knowledge of caribou from Gjoa Haven, Nunavut): Collaborative research contributions to co-management efforts. Polar Record.

Lyver, P.O.'B., and Łutsël K'é Dene First Nation. 2005. Monitoring barren-ground caribou body condition with Denésoliné traditional knowledge. Arctic 58(1):44-54.

https://doi.org/10.14430/arctic388 
McGrath, J.T. 2011. Isumaksaqsiurutigijakka: Conversations with Aupilaarjuk towards a theory of Inuktitut knowledge renewal. $\mathrm{PhD}$ thesis, Carleton University, Ottawa, Ontario.

Mearns, R. 2017. Nunavut, uqausivut, piqqusivullunajuqsittiarlavu (caring for our land, language and culture): The use of land camps in Inuit knowledge renewal and research. MA thesis, Carleton University, Ottawa, Ontario.

Miller, F.L., Barry, S.J., and Calvert, W.A. 2007. The role of seasonal migration in the near-total loss of caribou on southcentral Canadian Arctic Islands. Rangifer 27(Special Issue No. 17):243-245.

https://doi.org/10.7557/2.27.4.349

Moller, H., Berkes, F., Lyver, P.O.'B., and Kislalioglu, M. 2004. Combining science and traditional ecological knowledge: Monitoring populations for co-management. Ecology and Society 9(3): 2 .

https://doi.org/10.5751/es-00675-090302

Müller-Wille, L., and Müller-Wille, L.W. 2006. Inuit geographical knowledge one hundred years apart. In: Stern, P.R., and Stevenson, L., eds. Critical Inuit studies: An anthology of contemporary Arctic ethnography. Lincoln: University of Nebraska Press. 217-229.

Nadasdy, P. 1999. The politics of TEK: Power and the "integration" of knowledge. Arctic Anthropology 36(1/2):1-18.

2003. Reevaluating the co-management success story. Arctic 56(4):367-380. https://doi.org/10.14430/arctic634

2007. The gift in the animal: The ontology of hunting and human-animal sociality. American Ethnologist 34(1):25 - 43. https://doi.org/10.1525/ae.2007.34.1.25

Nagy, J.A., Gunn, A., and Wright, W.H. 2009. Population estimates for Peary caribou (Minto Inlet herd), Dolphin and Union caribou, and muskox on northwest Victoria Island, NT, July 2005. Manuscript Report No. 203. Inuvik: Department of Environment and Natural Resources, Government of the Northwest Territories.

Nagy, J.A., Johnson, D.L., Larter, N.C., Campbell, M.W., Derocher, A.E., Kelly, A., Dumond, M., Allaire, D., and Croft, B. 2011. Subpopulation structure of caribou (Rangifer tarandus L.) in Arctic and Subarctic Canada. Ecological Applications 21(6):2334-2348.

Natcher, D.C., and Hickey, C.G. 2002. Putting the community back into community-based resource management: A criteria and indicators approach to sustainability. Human Organization 61(4):350-363. https://doi.org/10.17730/humo.61.4.dem6fx3npep78xaq

Natcher, D.C., Davis, S., and Hickey, C.G. 2005. Co-management: Managing relationships, not resources. Human Organization 64(3):240-250.

https://doi.org/10.17730/humo.64.3.23yfnkrl2ylapjxw

Nickels, S., Furgal, C., Buell, M., and Moquin, H. 2006. Unikkaaqatigiit: Putting the human face on climate change: Perspectives from Inuit in Canada. Ottawa: Joint publication of Inuit Tapiriit Kanatami, Nasivvik Centre for Inuit Health and Changing Environments at Université Laval and the Ajunnginiq Centre at the National Aboriginal Health Organization.
Nishi, J.S., and Buckland, L. 2000. An aerial survey of caribou on western Victoria Island (5-17 June 1994). File Report No. 128. Kugluktuk and Yellowknife: Department of Resources, Wildlife, and Economic Development, Government of the Northwest Territories.

Nishi, J.S., and Gunn, A. 2004. An estimate of herd size for the migratory Dolphin and Union caribou herd during the rut (17-22 October 1997). File Report No. 131. Kugluktuk and Yellowknife: Department of Resources, Wildlife, and Economic Development, Government of the Northwest Territories.

Notzke, C. 1995. A new perspective in aboriginal natural resource management: Co-management. Geoforum 26(2):187-209. https://doi.org/10.1016/0016-7185(95)00019-h

Nuttall, M. 1992. Arctic homeland: Kinship, community, and development in Northwest Greenland. Toronto: University of Toronto Press.

NWMB (Nunavut Wildlife Management Board). 2004. The Nunavut wildlife harvest study. Prepared by H. Priest and P.J. Usher. Iqaluit: NWMB.

Okpakok, S. 2012. Interview in Gjoa Haven, Nunavut. Interviewed by R. Mearns and S. Robertson, 23 July 2012.

Osherenko, G. 1988. Wildlife management in the North American Arctic: The case for co-management. In: Freeman, M.M.R., and Carbyn L.N., eds. Traditional knowledge and renewable resource management in northern regions. Edmonton: University of Alberta, Boreal Institute for Northern Studies. $92-104$

Padilla, E., and Kofinas, G.P. 2014. "Letting the leaders pass": Barriers to using traditional ecological knowledge in comanagement as the basis of formal hunting regulations. Ecology and Society 19(2): 7. https://doi.org/10.5751/es-05999-190207

Parlee, B., Manseau, M., and Lutsël K'é Dene First Nation. 2005. Using traditional knowledge to adapt to ecological change: Denésoliné monitoring of caribou movements. Arctic 58(1):26-37. https://doi.org/10.14430/arctic386

Peter, A., and Urquhart, D. 1996. Co-management of the Porcupine caribou herd. Rangifer 16(Special Issue No. 9):273-276. https://doi.org/10.7557/2.16.4.1255

Peters, E.J. 2003. Views of traditional ecological knowledge in co-management bodies in Nunavik, Quebec. Polar Record 39(1):49-60. https://doi.org/10.1017/s0032247402002759

Polfus, J.L., Manseau, M., Simmons, D., Neyelle, M., Bayha, W., Andrew, F., Andrew, L., Klütsch, C.F.C., Rice, K., and Wilson, P. 2016. Łeghágots'enete (learning together): The importance of indigenous perspectives in the identification of biological variation. Ecology and Society 21(2): 18. https://doi.org/10.5751/ES-08284-210218

Puqiqnak, U. 2012. Interview in Gjoa Haven, Nunavut. Interviewed by S. Robertson; interpreted by L. Aaluk, 14 August 2012.

Putuguq, B. 2013. Interview in Gjoa Haven, Nunavut. Interviewed by S. Robertson; interpreted by S. Okpakok, 22 July 2013.

Qitsualik, S. 2013. Interview in Gjoa Haven, Nunavut. Interviewed by S. Robertson; interpreted by S. Okpakok, 22 July 2013. 
Røed, K.H., Staaland, H., Broughton, E., and Thomas, D.C. 1986. Transferrin variation in caribou (Rangifer tarandus L.) on the Canadian Arctic islands. Canadian Journal of Zoology 64(1):94-98.

https://doi.org/10.1139/z86-015

Ross, W.G. 1976. Inuit and the land in the nineteenth century. In: Freeman M.M.R., ed. Inuit land use and occupancy project, Vol. 2: Supporting studies. Ottawa: Department of Indian and Northern Affairs. 123-139.

Russell, D.E., Svoboda, M.Y., Arokium, J., and Cooley, D. 2013. Arctic Borderlands Ecological Knowledge Cooperative: Can local knowledge inform caribou management? Rangifer 33(Special Issue No. 21):71-78. https://doi.org/10.7557/2.33.2.2530

Sallerina, J. 2012. Interview in Gjoa Haven, Nunavut. Interviewed by R. Mearns and S. Robertson, 16 August 2012.

Siksik, D. 2012. Interview in Gjoa Haven, Nunavut. Interviewed by R. Mearns and S. Robertson; interpreted by L. Aaluk, 17 August 2012.

Sly, P.G., Little, L., Freeman, R., and McCullum, J. 2001. Updated state of knowledge report of the West Kitikmeot and Slave Geological Province. Picton, Ontario.

Spak, S. 2005. The position of Indigenous knowledge in Canadian co-management organizations. Anthropologica 47(2):233-246.

SRRB (Sahtu Renewable Resources Board). 2016. Belarewíle Gots'é Pekwę (caribou for all time): A Délịnę Got'ịnę plan of action. Tulit'a: SRRB.

Stern, G.A., and Gaden, A., eds. 2015. From science to policy in the western and central Canadian Arctic: An Integrated Regional Impact Study (IRIS) of climate change and modernization. Quebec City: ArcticNet.

Stevenson, M.G. 2006. The possibility of difference: Rethinking co-management. Human Organization 65(2):167-180.

https://doi.org/10.17730/humo.65.2.b2dm8thgb7wa4m53

Tavalok, T. 2012. Interview in Gjoa Haven, Nunavut. Interviewed by R. Mearns and S. Robertson; interpreted by L. Aaluk, 14 August 2012.

Tester, F.J., and Irniq, P. 2008. Inuit Qaujimajatuqangit: Social history, politics and the practice of resistance. Arctic 61(Supp. 1):48-61. https://doi.org/10.14430/arctic101

TG (Tłịch $Q$ Government). 2008. Monitoring caribou: The relationship between Tłich $\varrho$ laws and indicators of change. Report presented to the West Kitikmeot Slave Study Society. Behchokọ: TG.

Thomas, D.C., and Everson, P. 1982. Geographic variation in caribou on the Canadian Arctic islands. Canadian Journal of Zoology 60(10):2442-2454.

https://doi.org/10.1139/z82-312

Thorpe, N.L. 1997. The Tuktu and Nogak Project: Inuit knowledge about caribou and calving areas in the Bathurst Inlet region. Arctic 50(4):381-384.

https://doi.org/10.14430/arctic1121
1998. The Hiukitak School of Tuktu: Collecting Inuit ecological knowledge of caribou and calving areas through an elder-youth camp. Arctic 51(4):403-408.

https://doi.org/10.14430/arctic1084

- 2004. Codifying knowledge about caribou: The history of Inuit Qaujimajatuqangit in the Kitikmeot region of Nunavut, Canada. In: Anderson, D.G., and Nuttall, M., eds. Cultivating Arctic landscapes: Knowing and managing animals in the circumpolar North. London: Berghahn Books. 57-78.

Thorpe, N.L., Eyegetok, S., Hakongak, N., and Qitirmiut Elders. 2001a. Tuktu and Nogak project: A caribou chronicle. Final report to the West Kitikmeot /Slave Study Society. Ikaluktuuttiak, Nunavut.

Thorpe, N.L., Hakongak, N., Eyegetok, S., and the Kitikmeot Elders. 2001b. Thunder on the tundra: Inuit Qaujimajatuqangit of the Bathurst caribou. Victoria, British Columbia: Tuktu and Nogak Project.

Urquhart, D. 1996. Caribou co-management needs from research: Simple questions - tricky answers. Rangifer 16(Special Issue No. 9):263-271. https://doi.org/10.7557/2.16.4.1254

Usher, P.J. 1976. Inuit land use in the western Canadian Arctic: Tuktoyaktuk. In: Freeman M.M.R., eds. Inuit land use and occupancy project, Vol. 1: Land use and occupancy. Ottawa: Department of Indian and Northern Affairs. 24-26.

Watson, A. 2013. Misunderstanding the "nature" of comanagement: A geography of regulatory science and Indigenous knowledges (IK). Environmental Management 52(5):1085-1102.

https://doi.org/10.1007/s00267-013-0111-z

Wenzel, G.W. 1999. Traditional ecological knowledge and Inuit: Reflections on TEK research and ethics. Arctic 52(2):113-124. https://doi.org/10.14430/arctic916

— 2004. From TEK to IQ: Inuit Qaujimajatuqangit and Inuit cultural ecology. Arctic Anthropology 41(2):238-250. https://doi.org/10.1353/arc.2011.0067

Wheatley, M. 2003. Caribou co-management in Nunavut: Implementing the Nunavut land claims agreement. Rangifer 23(Special Issue No. 14):303-305.

https://doi.org/10.7557/2.23.5.1714

White, G. 2006. Cultures in collision: Traditional knowledge and Euro-Canadian governance processes in northern land-claim boards. Arctic 59(4):401-414. https://doi.org/10.14430/arctic289

WKSP (Workshop). 2013a. Verification workshop in Gjoa Haven, Nunavut involving William Aglukkaq and Paul Eleehetook. Facilitated by S. Robertson, S; interpreted by W. Aglukkaq, 19 August 2013.

- 2013b. Verification workshop in Gjoa Haven, Nunavut involving Jacob Keanik, Jonathan Hiqiniq, and Paul Aaluk. Facilitated by S. Robertson; interpreted by J. Keanik, 20 August 2013.

. 2013c. Verification workshop in Gjoa Haven, Nunavut involving Tommy Tavalok and Jerry Arqviq. Facilitated by S. Robertson; interpreted by B. Tavalok, 21 August 2013. 
2013d. Verification workshop in Gjoa Haven, Nunavut involving George Kamookak, Joseph Akoak and David Siksik. Facilitated by S. Robertson; interpreted by A. Carter, 22 August 2013.

. 2016a. Verification workshop in Gjoa Haven, Nunavut involving Susie Konana, David Siksik, Salomie Qitsualik, Donald Kogvik and Mary Aqilriaq. Facilitated by G. Ljubicic, S. Robertson, and R. Mearns; interpreted by S. Okpakok and L. Puqiqnak, 9-11 February 2016.

. 2016b. Verification workshop in Gjoa Haven, Nunavut involving Tommy Tavalok, David Siksik, Donald Kogvik and Paul Kamamalik. Facilitated by E. Val; interpreted by S. Okpakok, 8 September 2016.
WKSSS (West Kitikmeot Slave Study Society). 2008. West Kitikmeot Slave Study State of Knowledge Report - 2007 update. Report submitted to the WKSSS, Prepared by SENES Consultants Limited. Yellowknife: Department of Environment and Natural Resources, Government of the Northwest Territories.

Wohlberg, M. 2015. 80 years of food and friendship: Reindeer experiment leaves lasting legacy in the Delta. Tusaayaksat Magazine, Winter 2015-2016.

Zittlau, K., Nagy, J., Gunn, A., and Strobeck, C. 2009. Part 2. Genetic diversity among barren-ground and the Porcupine caribou herds. In: McFarlane, K., Gunn, A., and Strobeck. C., eds. Proceedings from the caribou genetics and relationships workshop Edmonton, Alberta, March 8-9, 2003. Manuscript Report No. 183. Yellowknife: Department of Natural Resources and Environment, Government of the Northwest Territories. $135-146$. 